University of Wollongong

Research Online

Faculty of Engineering and Information

Faculty of Engineering and Information

Sciences - Papers: Part A

Sciences

$1-1-2016$

Experimental investigation of GFRP-reinforced and GFRP-encased square concrete specimens under axial and eccentric load, and four-point bending test

Muhammad N. S Hadi

University of Wollongong, mhadi@uow.edu.au

Jim Youssef

University of Wollongong, jy201@uowmail.edu.au

Follow this and additional works at: https://ro.uow.edu.au/eispapers

Part of the Engineering Commons, and the Science and Technology Studies Commons

Research Online is the open access institutional repository for the University of Wollongong. For further information contact the UOW Library: research-pubs@uow.edu.au 


\title{
Experimental investigation of GFRP-reinforced and GFRP-encased square concrete specimens under axial and eccentric load, and four-point bending test
}

\author{
Abstract \\ This paper presents the results of an experimental study on the axial and flexural behavior of square \\ concrete members reinforced with glass fiber-reinforced polymer (GFRP) bars and embedded with \\ pultruded GFRP structural sections under different loading conditions. The main parameters investigated \\ in this study were the influence of the type of internal reinforcement (steel bars, GFRP bars and pultruded \\ GFRP structural I-sections and C-sections) and magnitude of load eccentricity on the flexural and \\ compressive behavior of square concrete members. To fulfil the objectives of this study, 16 reinforced \\ concrete specimens were tested, of which 12 were tested as columns under compression loading and 4 \\ were tested as beams under flexural loading. The concrete specimens were square in cross section with \\ a side dimension of $210 \mathrm{~mm}$ and a height of $800 \mathrm{~mm}$. The experimental results have shown that the steel- \\ reinforced specimens have a higher loadcarrying capacity than specimens reinforced with GFRP bars for \\ all loading conditions. In addition, for concentrically loaded specimens, steel-reinforced specimens have a \\ better ductile performance than specimens reinforced with GFRP bars. In terms of eccentric loading, \\ specimens reinforced with GFRP bars experienced similar ductility as compared to the corresponding \\ steel-reinforced specimens. However, the eventual failure mode of specimens reinforced with GFRP bars \\ was sudden and brittle in nature. However, specimens encased with GFRP structural sections have a \\ higher load-carrying capacity but considerably lower ductility than the steel-reinforced and GFRP bar- \\ reinforced specimens.
}

\section{Keywords}

load, concrete, specimens, under, axial, eccentric, experimental, four, investigation, bending, test, gfrp, reinforced, encased, point, square

\author{
Disciplines \\ Engineering | Science and Technology Studies
}

\section{Publication Details}

Hadi, M. N. S. \& Youssef, J. (2016). Experimental investigation of GFRP-reinforced and GFRP-encased square concrete specimens under axial and eccentric load, and four-point bending test. Journal of Composites for Construction, 20 (5), 04016020-1-04016020-16. 


\section{Abstract}

6 This paper presents the results of an experimental study on the axial and flexural behavior of 7 square concrete members reinforced with glass fiber reinforced polymer (GFRP) bars and embedded with pultruded GFRP structural sections under different loading conditions. The main parameters investigated in this study were the influence of the type of internal reinforcement (steel bars, GFRP bars and pultruded GFRP structural I-sections and Csections) and magnitude of load eccentricity on the flexural and compressive behavior of square concrete members. In order to fulfil the objectives of this study, 16 reinforced concrete specimens were tested, of which 12 were tested as columns under compression loading and 4 were tested as beams under flexural loading. The concrete specimens were square in cross section with a side dimension of $210 \mathrm{~mm}$ and a height of $800 \mathrm{~mm}$. The experimental results have shown that the steel reinforced specimens have a higher load carrying capacity than specimens reinforced with GFRP bars for all loading conditions. In addition for concentrically loaded specimens, steel reinforced specimens have a better ductile performance than specimens reinforced with GFRP bars. In terms of eccentric loading, specimens reinforced with GFRP bars experienced similar ductility as compared to the

\footnotetext{
${ }^{1}$ Associate Professor, School of Civil, Mining and Environmental Engineering, University of Wollongong, Wollongong, NSW 2522, Australia. Email: mhadi@uow.edu.au, *Corresponding Author

${ }^{2} \mathrm{Ph} . \mathrm{D}$. Candidate, School of Civil, Mining and Environmental Engineering, University of Wollongong, Wollongong, NSW 2522, Australia. Email: jy201@uowmail.edu.au
} 
21 corresponding steel reinforced specimens. However, the eventual failure mode of specimens reinforced with GFRP bars was sudden and brittle in nature. On the other hand, specimens encased with GFRP structural sections have a higher load carrying capacity but considerably lower ductility than the steel reinforced and GFRP bar reinforced specimens.

CE Database subject headings: Columns; Application of FRPs; Composite systems; Hybrid structures; Pultruded shapes

\section{Introduction}

Based on the literature, understanding the behavior of concrete members reinforced with FRP bars has been the main objective of many researchers. In the last decade, there has been extensive research on the flexural and shear behavior of concrete members reinforced with FRP bars (Thériault and Benmokrane 1998; and Benmokrane et al. 1996). Therefore, the level of understanding of the flexural behavior of FRP-reinforced concrete beams has reached a stage where design standards and guidelines around the world have been developed for the design of these members. However, the structural behavior of columns reinforced with FRP bars has been examined by only a few limited studies (Mohamed et al. 2014; De Luca et al. 2010; and Hadi et al. 2015). Consequently, ACI 440.1R-06 (ACI 2006) does not recommend using FRP bars in columns as longitudinal reinforcement. On the other hand, CSA S806-12 (CSA 2012) neglects the compressive contribution of FRP longitudinal reinforcement. Given the lack of experimental data about FRP reinforcement in compression members, this study 40 aims to expand the understanding of the compression behavior of concrete columns internally 41 reinforced with GFRP bars.

Furthermore, most of the findings of studies investigating FRP reinforced concrete columns have been reported based on testing under concentric loading (Afifi et al. 2014;Tobbi et al. 2012; and De Luca et al. 2010), whereas only a few studies presented investigations of 
columns subjected to eccentric loading, for example Xue et al. (2014) and Issa et al. (2011). In reality columns are not subjected to perfect concentric loading but are influenced by a combination of axial compression loads and bending moments (Hadi 2006). Even for columns nominally carrying only axial compression load, bending moments always exist. These bending moments are introduced by unintentional load-eccentricities and by out-ofstraightness of the constructed column (Warner et al. 2007). Consequently, this study investigates the behavior and performance of FRP-reinforced concrete columns subjected to eccentric loading.

In recent times, GFRP pultruded profiles low self-weight, non-corrosive nature, low maintenance requirements and high durability have allowed them to become a competitive replacement as a primary structural material in place of steel and reinforced concrete. However, their application is still hindered by their sensitivity to buckling, high deformability and the lack of design codes (Correia et al. 2013). Having said this, there is an interesting potential for the use of GFRP pultruded profiles in hybrid GFRP-concrete structural elements, either for new constructions or for the rehabilitation of existing structures, as reported by many researchers. Kwan and Ramli (2013) conducted a study of completely encasing a pultruded GFRP I-section in a concrete beam for reinforcing purposes. Correia et al. (2009) developed a GFRP-concrete hybrid beam composed of pultruded GFRP I-sections connected to a concrete layer on the top flange. However, there have been no studies available on structural GFRP sections encased concrete columns.

Another focus of this study is the encasement of pultruded GFRP sections in concrete columns to achieve a hybrid GFRP-concrete member. The primary objective of encasing

67 GFRP pultruded structural sections in concrete is to improve the load carrying capacity of FRP reinforced concrete members. The secondary objective of encasing the GFRP sections in 
concrete is to prevent its buckling phenomenon and increase its flexural stiffness. In order to

70 investigate the viability of encasing GFRP sections in concrete an experimental program has been designed and executed. This paper summarises the results of an experimental program investigating the behavior of GFRP reinforced and GFRP encased concrete columns and beams. Parameters investigated include the magnitude of load eccentricity and type of internal reinforcement with steel reinforced, GFRP reinforced, GFRP I-section encased and GFRP C-sections encased concrete specimens tested under compressive and flexural loading.

\section{Design of Specimens}

The test matrix was organized to investigate the influence of reinforcement type (steel bars, GFRP bars and encased pultruded GFRP structural sections) and magnitude of load eccentricity on the compressive and flexural behavior of square concrete specimens. Table 1 shows the test matrix. In this study the specimens were classified into four groups: reference steel reinforced (RS), reference GFRP reinforced (RF), GFRP I-section encased (I) and GFRP C-sections encased (C). Each group consisted of four specimens; one specimen was tested concentrically, one tested under $25 \mathrm{~mm}$ eccentricity, one tested under $50 \mathrm{~mm}$ eccentricity and the last specimen was tested as a beam under four point loading test. Each specimen had a square cross section with a side dimension of $210 \mathrm{~mm}$ and a height of 800 $\mathrm{mm}$.

The notation of the specimens consists of two parts: the first part is either a letter "RS", "RF", "I" and "C" stating the name of the group, and the second part is either " 0 ", " 25 ", "50" or "B" which indicates the eccentricity under which the specimens are subjected to with the letter "B" denoting a beam tested under flexural loading. For example, Specimen RS-50 is a concrete column reinforced with steel and tested with the load applied at an eccentricity of 50 $\mathrm{mm}$. 
93 The reinforcement details of all the groups of specimens are shown in Figure 1. The specimens of the first group (Group RS) were considered as a reference group designed with longitudinal and transverse steel reinforcement in accordance with AS3600-2009 (Standards Australia 2009). The concrete standard specifies a minimum longitudinal reinforcement ratio of $1 \%$. For this study the internal longitudinal steel reinforcement ratio was designed as the lowest ratio required by the standard. Therefore, the specimens were designed with four N12 (12 mm deformed bars with $500 \mathrm{MPa}$ nominal tensile strength) as longitudinal reinforcement with a reinforcement seel ratio of $1.03 \%$. The shear reinforcement provided was R10 stirrups (10 mm diameter plain bars with $250 \mathrm{MPa}$ nominal tensile strength) spaced at $50 \mathrm{~mm}$ center to center. Specimens of the second group (Group RF) were designed to have similar

103 longitudinal and transverse reinforcement ratios as the specimens in the reference steel group 104 (RS) but instead of steel, these specimens were reinforced with GFRP bars. These specimens were designed in accordance with ACI 440.1R-06 (ACI 2006). The spacing of the shear reinforcement for the two reference specimens was dictated by the design of the GFRP

107 reinforced specimens. The amount of stirrups was chosen to ensure that the beam specimen

108 reinforced with GFRP bars would fail in flexure rather than in shear and a consistent 109 reinforcement arrangement was used for all the reference specimens. The nominal diameter 110 of the longitudinal GFRP reinforcement and transverse reinforcement was 12.7 and $9.5 \mathrm{~mm}$, 111 respectively. The geometry of the stirrups used in the reference specimens is shown in Figure 1122.

113 Specimens of the third group (Group I) were designed with an encased pultruded GFRP I114 section. The encased I - section had a nominal height of $152.4 \mathrm{~mm}$, nominal flange width of $115152.4 \mathrm{~mm}$ and nominal thickness of $9.5 \mathrm{~mm}$. The GFRP I-section was completely encased in 116 the concrete specimens for reinforcing purposes. Similarly, specimens of the fourth group 117 (Group C) were designed with encased GFRP C-sections. The C-sections had a nominal 
118 height of $152.4 \mathrm{~mm}$, nominal flange width of $42.9 \mathrm{~mm}$ and a nominal thickness of $9.5 \mathrm{~mm}$, as

119 shown in Figure 1.Two GFRP C-sections were positioned side by side in a box arrangement

120 to serve as encased longitudinal reinforcement and to confine the internal concrete core. The

121 GFRP reinforcement ratio of the Specimens in Group I and C were similar and at a value of

122 approximately $9.44 \%$. Therefore, a direct comparison of the influence of the shape of

123 encased structural GFRP section on the structural behavior could be analysed from these two

124 groups of specimens. In the design for shear it was assumed that the I-section and C-section

125 would provide some shear resistance in the beam specimens as opposed to the negligible

126 shear resistance of the longitudinal bars in the reference beam specimens. Therefore,

127 specimens in Group I and Group C were provided with steel R10 stirrups (10 mm diameter

128 plain bars) at an increased center to center spacing of $100 \mathrm{~mm}$, as compared to the reference

129 specimens. The main purpose of the stirrups was to: increase the shear capacity of the

130 specimen; confine the concrete core between the web of the I-section and extremities of the

131 specimen; position the C-sections in place as a box arrangement; and to prevent the GFRP

132 sections from outward lateral buckling. It should be noted that the stirrups for these

133 specimens and that of the reference steel specimens were of the same batch but varied with

134 the radius of the bend. The concrete cover at the top and bottom of the specimens was

135 maintained at $20 \mathrm{~mm}$, while the side covers for all the groups of specimens varied slightly

136 depending on the tolerances in the internal reinforcement cages, as shown in Figure 1.

137 To ensure the failure mode occurred in the instrumented region of the column specimens (at

138 mid-height) and to prevent premature failure, the ends of each specimen were strengthened

139 and confined with two layers of CFRP sheets in the circumferential direction. However,

140 wrapping CFRP sheets around the sharp edges of square specimens has been reported to

141 result in stress concentration and premature failure at these locations (Ozbakkaloglu 2013).

142 Therefore, the top and bottom of the specimens at a length of $100 \mathrm{~mm}$ were rounded to 
143 provide a curved round finish to wrap the CFRP sheets. A corner radius of $20 \mathrm{~mm}$ was

144 applied at these locations. In addition, for each eccentrically loaded column specimen, two

145 layers of CFRP wrap were applied longitudinally on the tension zone in combination with the

146 two layers wrapped circumferentially to ensure no premature tensile failure occurred at these

147 regions. These longitudinal sheets were $100 \mathrm{~mm}$ in length. Furthermore, the four beam

148 specimens were rounded at a radius of $20 \mathrm{~mm}$ throughout the length of the specimen. This

149 was done as a precaution if the beam specimens were required to be wrapped by CFRP in the

150 shear zones, at the outer thirds of the beam to ensure failure occurs due to bending rather than

151 shear.

\section{Specimen Preparation}

153 The formwork used for moulding the concrete column and beam specimens was made from

$15417 \mathrm{~mm}$ thick plywood (formply). Before pouring of the concrete, the formwork was vertically

155 fixed to a base and tied together laterally with timber, in order to prevent any movement while pouring and vibrating the concrete. Normal-strength ready-mix concrete with an intended compressive strength of $32 \mathrm{MPa}$ was supplied by a local supplier.

The completed reinforcement cages for the four groups of specimens are shown in Figure 3. The GFRP square stirrups used in the Group RF specimens were manufactured by Pultrall Inc. (2012). GFRP bars cannot be bent after they have been cured (polymerized) and the only

161 way to produce bends was during the manufacturing process. The radius of the bends of the

162 square GFRP stirrups is $12.7 \mathrm{~mm}$. The steel stirrups used in the Group RS specimens were 163 fabricated having similar dimensions to that of the GFRP stirrups but varied in the radius of 164 the bends, as shown in Figure 2. The radius of the bends of the steel stirrups was $40 \mathrm{~mm}$. The 165 difference in corner bend radius of stirrups between the two reference specimens meant that 166 the center to center spacing of the longitudinal bars was slightly greater for the Group RF 
167 specimens as compared to the Group RS specimens. On the other hand, the steel stirrups for

168 Group I and Group C specimens were fabricated in the lab with a corner bend radius of 6.5

$169 \mathrm{~mm}$, to ensure the stirrups fit over the GFRP sections and maintain the required cover.

170 For the Group I and C specimens, steel stirrups were bonded onto the GFRP sections with

171 silicone at $100 \mathrm{~mm}$ center to center spacing. Due to the symmetry of the GFRP sections,

172 hooks could not be made for the steel stirrups. Instead the overlap regions, which were

173 approximately $80 \mathrm{~mm}$ long were continuously stitch welded together to ensure the stirrups

174 would provide adequate confinement to the internal concrete core and GFRP sections. The

175 welded overlap regions were positioned to be parallel to the web of the I-section. The encased

176 section of the Group $\mathrm{C}$ specimens consisted of two $\mathrm{C}$ sections forming a box section as

177 shown in Figure 1. To form this profile, a square wooden piece of the required dimension was

178 temporarily glued with silicone onto two C-sections positioned side by side, at both the top

179 and bottom. Once the GFRP C-sections were ready to be placed into the formwork, the wood

180 pieces holding the two sections in place were removed with the steel stirrups holding the

181 GFRP sections in place. To ensure that the concrete and GFRP sections had adequate bond

182 and no bond-slip occurred, a layer of sand was coated onto the smooth sides of the GFRP I-

183 sections and box C-sections. It was assumed that by coating the largest outside surface area of

184 the sections, an adequate bond would occur between the sections and concrete. Therefore,

185 only the outside faces of both the flanges of the I-section and the long dimension of the C-

186 sections were sand coated along the full height as shown in Figure 4. This was done by first

187 applying a thin layer of epoxy resin on the GFRP sections and then placing coarse sand on

188 the resin.

189 As mentioned above, for the purpose of avoiding premature failure, the ends of each column

190 specimen were strengthened and confined with two layers of CFRP sheets in the hoop 
191 direction. To avoid stress concentrations from the sharp edges of the specimens, rounded styrofoam (polystyrene) sets of $20 \mathrm{~mm}$ radius and $100 \mathrm{~mm}$ in length were glued to the

193 internal edges of the formwork with silicone at the top and bottom ends to provide a curved

194 round finish to wrap the CFRP sheets. The connection between this corner radius and the

195 sharp edges of the column specimen created a point of stress concentration which is discussed

196 below. In addition, the four beam specimens were provided with $20 \mathrm{~mm}$ radius foam sets

197 throughout the length.

198 After casting, a wet mesh was placed over all the specimens and was watered daily and 199 covered with plastic sheets to maintain the moisture in the concrete and allow for adequate 200 curing. After 28 days of this curing process, the specimens were removed from the formwork

201 and were wrapped with CFRP as explained above. The adhesive used to bond the CFRP to 202 the concrete was a mixture of epoxy resin and hardener at 5:1 ratio.

\section{Material Properties}

204 All the concrete specimens were cast on the same day with ready-mixed, normal strength 205 concrete provided by a local supplier. The concrete compressive strength was carried out and 206 determined in accordance with AS 1012.9-1999 (Standards Australia 1999). A total of five

207 cylinders having a diameter of $100 \mathrm{~mm}$ and height of $200 \mathrm{~mm}$ were tested to obtain the 28

208 day concrete compression strength of $29.3 \mathrm{MPa}$. In addition, the concrete compression 209 strength at the first day and last day of specimen testing was determined to be $31 \mathrm{MPa}$ and $210 \quad 35.30 \mathrm{MPa}$, respectively.

211 Deformed steel N12 bars were used as longitudinal reinforcement in Group RS specimens 212 and plane steel R10 bars were fabricated into square stirrups to serve as transverse 213 reinforcement in Group RS, I and C specimens. Five samples of each diameter were tested in 
214 accordance with AS 1391- 2007 (Standards Australia 2007) to determine the tensile

215 properties of the reinforcing steel bars and stirrups as shown in Table 2.

216 Sand coated GFRP bars and GFRP stirrups were used to reinforce the Group RF specimens.

217 No. 4 (\#4) GFRP bars of $12.7 \mathrm{~mm}$ nominal diameter were used as longitudinal reinforcement

218 and No. 3 (\#3) GFRP bars of $9.5 \mathrm{~mm}$ nominal diameter were used as square stirrups for the

219 transverse reinforcement. The GFRP reinforcement was supplied with a sand-coated surface

220 to improve the bond performance between the bars and surrounding concrete. Four samples

221 of each diameter were tested in accordance with ASTM D7205-06 (2011) to determine the

222 tensile properties of the GFRP bars, as shown in Table 3. It should be noted that the No. 3,

$2239.5 \mathrm{~mm}$ diameter stirrups made by bending GFRP bars have their own production lot number

224 and thus they were not from the same batch as the No. 3, 9.5 mm diameter straight bars that

225 were tensile tested. According to Ehsani et al. (1995) the minimum ratio of radius of bend to

226 the stirrup diameter is three. However, in this study the radius of bend was only $12.7 \mathrm{~mm}$ due

227 to manufacturing errors. In addition, according to Pultrall, Inc. (2012) the tensile strength of

228 the GFRP stirrups straight portions is lower than the tensile strength of the corresponding

229 straight bars with the same diameter. However, for the purpose of this study it assumed that

230 the properties of the tested $9.5 \mathrm{~mm}$ diameter straight bars are equal to that of the straight

231 portions of the $9.5 \mathrm{~mm}$ diameter stirrups. Furthermore, Nanni et al. (1998) reported that the

232 tensile strengths in the bend portion of FRP bars are 40 to $50 \%$ lower compared to that of a

233 straight bar due to stress concentrations or fibre bending. Lastly, due to the small dimensions

234 of the GFRP stirrups, the manufacturing process was by hand which resulted in the regions at

235 the bend radius being relatively square in cross section rather than circular which may have

236 posed a further region of stress concentration. 
237 GFRP pultruded I-sections and C-sections were used in the specimens of Group I and C, 238 respectively and they were supplied by GRP Australia (GRP, n.d). These GFRP sections are 239 orthotropic materials with the properties varying in each direction. The fibres are laid mainly 240 in the longitudinal direction, which makes these sections stronger in the longitudinal direction 241 as compared with the transverse direction. The tensile properties of the GFRP pultruded 242 sections were determined based on the test method ISO 527-4 (1997) and are shown in Table 243 4. Five coupon samples from each GFRP C-section, web of the I-section and flange of the I244 section with nominal dimensions of $300 \mathrm{~mm}$ long and $25 \mathrm{~mm}$ wide were extracted and tested 245 using a screw-driven material testing machine known as the $500 \mathrm{kN}$ Instron 8033 machine. 246 The compressive properties of the GFRP pultruded sections were determined based on the 247 test method ASTM D 695 (2002) and are shown in Table 4. Eleven coupon samples from each GFRP C-section, web of the I-section and flange of the I-section with nominal dimensions of $37.6 \mathrm{~mm}$ long and $12.7 \mathrm{~mm}$ wide were extracted and tested under compression by direct end loading using the Instron 8033 machine. Five samples each from the C-section and web and flange of the I-section were instrumented with strain gauges to measure the compressive modulus. It should be noted that compression testing of pultruded samples is difficult due to the high longitudinal strength and low transverse strength of the material. As a result, the ends of the coupons failed by splitting and the property measured may not be the actual compressive strength but represent the composite bearing strength. Having said this, the average compressive strength and modulus obtained from testing were higher than those

257 values provided by the supplier (compressive strength of $207 \mathrm{MPa}$ and compressive modulus of $17.2 \mathrm{GPa}$ ) and were adopted in this study, although they may not represent the true compressive properties due to premature failure by bearing. Originally, based on the supplier's specifications it was assumed that the GFRP I-section and C-sections had similar 
material properties. However, from material testing it can be seen that the two shapes of

262 GFRP sections varied in tensile and compressive properties as shown in Table 4.

\section{Instrumentation and Specimen Testing}

264 All of the specimens were tested with the Denison $5000 \mathrm{kN}$ compression testing machine until failure. The column specimens were capped with high strength plaster at the top and bottom ends to ensure the bearing surfaces were parallel and the load was distributed evenly during testing. The typical compression testing setup of the column specimen is shown in Figure 5. The eccentric load was applied to the column specimen by an eccentric loading system manufactured at the University of Wollongong, as illustrated by Hadi and Widiarsa (2012) and shown in Figure 5. The loading system comprised a set of high strength steel loading heads which were attached to both ends of the columns. The loading heads consisted of two parts: a $50 \mathrm{~mm}$ thick square plate, called the adaptor plate and a $25 \mathrm{~mm}$ thick bottom plate that had a ball joint, known as the bottom plate. The eccentric load was applied to the column by the interaction of the adaptor plate and bottom plate. The load generated by the testing machine was transferred to the adaptor plate by the bottom plate through the ball joint. The ball joint was offset from the center of the column by the amount of eccentricity required ( 25 or $50 \mathrm{~mm}$ ). For columns tested under concentric loading, only the adaptor plate was used to apply the load. The line of application of eccentricity load for the column specimens is shown in Figure 1.

280 External instrumentation was used to obtain the displacement data of the column specimens.

281 To measure the axial displacement of the column specimens, two linear variable differential transformers (LVDTs) were directly connected to the testing machine at opposite ends. In addition to this, for the eccentrically loaded columns a laser triangulation was positioned horizontally at mid-height of the columns on the tension side in order to measure the lateral 
deflections $(\delta)$ as shown in Figure 5. The LVDTs and laser triangulation were connected to a

286 data logger to record readings on a control computer at a user controlled time interval.

287 Depending on the amount of data, the time interval for recording of the data varied from 2 to

2885 seconds. The data read from the instrumentations were recorded at the same time as the

289 load data were recorded by the testing machine. Prior to the start of testing, calibration was

290 carried out to ensure the specimens were placed at the center of the testing machine and the

291 instrumentations were positioned and operating adequately. The concentrically loaded

292 specimens were initially preloaded to approximately $10-20 \mathrm{kN}$ and then tested under

293 displacement control with a loading rate of $0.3 \mathrm{~mm} / \mathrm{min}$ until failure. On the other hand, the

294 eccentrically loaded specimens were initially loaded to $100 \mathrm{kN}$ (approximately $10 \%$ of the

295 anticipated ultimate capacity) under force control with a loading rate of $2.5 \mathrm{kN} / \mathrm{s}$ and then

296 unloaded to a load of $20 \mathrm{kN}$ to ensure adequate contact between the loading plates. The test

297 was then resumed using displacement control with a loading rate of $0.3 \mathrm{~mm} / \mathrm{min}$ until failure

298 of the specimens.

299 As highlighted above, four of the specimens were tested as beams under flexural loading in

300 order to determine the flexural capacity. The beam specimens were subjected to pure bending

301 by a four point loading system manufactured at the University of Wollongong, as described

302 by Hadi and Widiarsa (2012). The typical flexural testing setup of the beams is shown in

303 Figure 6. The bottom rig was placed diagonally on the bottom plate of the testing machine

304 with the beam specimen then placed on top of the bottom rig. The top rig was then placed on

305 the top of the beam. The beams were loaded with a pin support at one end and a roller support

306 at the other. In addition, one contact area on the top rig was provided with a roller. To

307 measure the midspan deflection of the beam, a laser triangulation was placed vertically

308 underneath the bottom rig through which the laser is shot through a slot in the bottom rig. The

309 test for the beams initially started with force control at a loading rate of $2.5 \mathrm{kN} / \mathrm{s}$ up to a load 
310 of $25 \mathrm{kN}$ (approximately $10 \%$ of the anticipated ultimate capacity). This level of preload

311 ensured the proper interaction of the steel rigs and specimen at the start of testing. The test

312 was then continued using displacement control under a loading rate of $0.3 \mathrm{~mm} / \mathrm{min}$ until

313 failure of the specimens. During testing there were issues with the premature failure

314 mechanism of the beams due to bearing failure. The sections below describe this problem and

315 solutions in detail. For each of the column and beam specimens, the test was terminated

316 either once the load dropped down to approximately $35 \%$ of the first maximum peak load or

317 due to the failure of the GFRP reinforcements.

\section{Behavior of Column Specimens}

319 To analyse the structural behavior of the column specimens, the relationship of the applied

320 axial load and the corresponding axial and lateral displacements were plotted. Based on these

321 relationships, the strength and ductility of each group of specimens under different types of eccentric loading were analysed.

323 Ductility can be defined as the ability of structural material to deform plastically without fracturing. Ductility is commonly measured by the ratio of the ultimate displacement $\left(\delta_{\mathrm{u}}\right)$ divided by the yield displacement $\left(\delta_{\mathrm{y}}\right)$, which can be written as follows:

$$
\lambda=\frac{\delta_{u}}{\delta_{y}}
$$

326 The yield displacement is assumed to be the axial displacement at the yield load or at the

327 limit of the elastic behavior, as defined by Pessiki and Pieroni (1997). Various authors have 328 used different percentages of the peak load to calculate the corresponding ultimate 329 displacement. Pessiki and Pieroni (1997) calculated the ultimate displacement as the axial 330 displacement at an axial load equal to $85 \%$ of the peak load in the descending part of the axial 
331 load - displacement curve. Other research studies calculated the ultimate displacement at $80 \%$

332 of the peak load (Sheikh and Legeron 2014).

333 In this study two methods were used to calculate the ductility of the columns. For the first 334 method the ductility $(\lambda)$ was calculated based on the ratio of the ultimate displacement $\left(\delta_{\mathrm{u}}\right)$ 335 divided by the yield displacement $\left(\delta_{\mathrm{y}}\right)$, as shown in Equation 1. In terms of notation herein, $336 \mathrm{P}_{\max }$ is the first maximum load achieved just after the initial linear region and $\mathrm{P}_{\text {peak }}$ is the peak 337 load after concrete cover spalling and is obtained for columns experiencing a strength 338 increase after concrete spalling $\left(\mathrm{P}_{\text {peak }}>\mathrm{P}_{\max }\right)$. For the steel reinforced columns, no increase 339 in strength occurred after concrete spalling and the ultimate displacement was taken at $80 \%$ 340 of $\mathrm{P}_{\max }$. However, for the GFRP reinforced and GFRP encased columns, the ultimate 341 displacements was taken at either the first fracture load of the GFRP reinforcement $\left(\mathrm{P}_{\text {fracture }}\right)$, 342 at the peak load $\left(\mathrm{P}_{\text {peak }}\right)$ or at $80 \%$ of $\mathrm{P}_{\text {peak }}$, whichever gave the smallest axial displacement. 343 For GFRP reinforced columns experiencing an increase in strength after concrete spalling it 344 was safer to define the ultimate displacement at this peak load rather than at $80 \%$ of peak 345 load considering the unpredictable and sudden brittle failure of the internal GFRP 346 reinforcement after peak load. This is further discussed in the below sections.

347 For the second method, the ductility was calculated based on the ratio of the area under the 348 axial load-displacement curve up to the ultimate displacement $\left(\mathrm{A}_{2}\right)$, divided by the area under 349 the curve up to the yield displacement $\left(\mathrm{A}_{1}\right)$, which is written as follows:

$$
\lambda=\frac{A_{2}}{A_{1}}
$$

350 The same definitions of the ultimate and yield deflections were used for the two methods. 


\section{Behavior of Column Specimens under Concentric Loading}

352 The first specimen from each group was tested under concentric loading. The experimental results of the concentrically loaded column specimens are summarized in Table 5 with the axial load-displacement curves shown in Figure 7. Initially, all the specimens experienced similar behavior, with the ascending region of the load-displacement curve being almost linear up to the beginning of concrete spalling. As mentioned above the column edges were rounded at the top and bottom at a width of $100 \mathrm{~mm}$ to allow for the wrapping of CFRP sheets. The connection between this corner radius and the sharp edge of the specimen created a point of stress concentration. This resulted in cracks first appearing at the top of the specimen at this weak transition zone. As the test continued the cracks started to propagate to all sides of the specimen and eventually along its instrumented region. After the maximum load $\left(\mathrm{P}_{\max }\right)$ was achieved, the load dropped as a result of the sudden spalling of the concrete cover.

A decrease in maximum load of $4.8 \%$ relative to Specimen RS-0 was achieved for Specimen RF-0. Specimen I-0 achieved the highest maximum load of all the concentrically loaded specimens with an increase of maximum load of $5.6 \%$ and $10.9 \%$ relative to the RS-0 and RF-0 Specimens, respectively. Similarly, an increase of maximum load of $2.6 \%$ and $7.8 \%$ in comparison to the RS-0 and RF-0 specimens was achieved for Specimen C-0, respectively. After the maximum load was achieved spalling of the concrete cover occurred which resulted in a decrease in the cross-sectional area resisting the load with a corresponding drop in the load carrying capacity of the specimens. After this drop in the capacity the load then stabilised for Specimen RS-0 and RF-0. This meant that the passive confinement provided by

373 the stirrups was activated to prevent the lateral expansion of the concrete core and the specimen was able to sustain the load up until failure. 
375 The cracking appearance and failure modes of the concentrically loaded specimens after 376 failure are shown in Figure 8 and Figure 9. The axial - displacement curve of Specimen RS-0

377 shows the behavior up until an axial displacement of $30 \mathrm{~mm}$. This was the point at which the 378 data limit of the data logger was exhausted. At this point, the specimen was still able to carry 379 approximately $63 \%$ of the maximum load. It should be noted that the test was continued to an 380 axial displacement of $50 \mathrm{~mm}$, as obtained from the machine readings rather than the average 381 readings of the LVDTs. Interestingly at this displacement the specimen was still able to carry approximately $46 \%$ of the maximum load, with the load gradually decreasing. After this point the test was terminated and it was observed that after the concrete spalled off, all four longitudinal bars had substantially buckled and some of the ties were deformed and distorted as a result of the concrete core dilating, as shown in Figure 9a. Specimen RS-0 experienced the most ductile behavior of the four specimens. Due to stress concentrations at the rounded corners as mentioned above, the buckling of the bars was predominately at the top third of the specimen.

Unlike Specimen RS-0, Specimen RF-0 failed in a brittle manner as result of the explosive failure of the internal reinforcement at a load of $1125.7 \mathrm{kN}$ and an axial ultimate displacement of $7.72 \mathrm{~mm}\left(\delta_{\mathrm{u}}\right)$. After this failure point the load dropped down drastically. It was unclear whether the first failure was due to the rupture of a stirrup or due to the crushing or buckling and explosive fracture of a longitudinal bar. The rupture of the tie occurred at the bend portion at the connection with a longitudinal bar at mid-height of the specimen. This was anticipated as the bend radius of the ties was $12.7 \mathrm{~mm}$, which was well below the recommended radius based on the required ratio of the bend radius and tie diameter, as reported by others and mentioned above. Furthermore, it was seen that one tie experienced slippage (at the splice locations) of the overlap regions resulting in a potentially inadequate confinement to the concrete core. It should be noted that the GFRP ties were spliced by steel 
400 ties at the overlap regions. The exact timing of the rupture and slippage of the tie could not be 401 established. The test was continued until all four longitudinal bars had failed in compression 402 by complete crushing, with each drop in the load-displacement curve representing the 403 explosive fracture of each bar. At the end of testing there was considerable crushing of the 404 concrete core. As a result during the removal of the steel loading caps by force, the specimen 405 separated into two regions with the four bars split into two, although Figure $9 \mathrm{~b}$ shows the two 406 regions placed on top of each other for completeness.

407 The GFRP encased specimens showed little ductile behaviour after the maximum load was reached as compared to the other two specimens. Not long after the maximum load was achieved for Specimen I-0, a small cracking noise was heard on one of the flanges of the Isection at a load of $1257 \mathrm{kN}$ and corresponding axial ultimate displacement of $4.65 \mathrm{~mm}\left(\delta_{\mathrm{u}}\right)$.

411 This load was assumed to be the first failure load of the specimen. At this point, the load 412 dropped with a few more cracking noises being heard as the concrete cover started to 413 completely spall off. Eventually, as the test progressed a larger cracking noise occurred on 414 the opposite flange at a load of $965 \mathrm{kN}$ and axial displacement of $8 \mathrm{~mm}$ with a large drop in 415 load occuring. This point is assumed to be the second fracture load. Therefore, on observation 416 it is clearly seen that the two flanges of the I-section at mid-height failed in compression due 417 to the material crushing and delamination of the fibers at the different loads. The crushing 418 occurred along the flange with the combination of axial load and pressure from the concrete 419 core resulting in the crushed area delaminating outwards as shown in Figure 9c. Similarly, 420 Specimen C-0 experienced a brittle failure manner as a result of the progressive crushing of 421 both the GFRP C-sections at different locations after the first maximum load. Just before the 422 first fracture of the GFRP sections, a small cracking noise could be heard, followed by a loud noise. Two other explosions occurred which resulted in the load suddenly dropping each time due to the subsequent damage of the material. Crushing and splitting of the C-sections 
occurred on the flange, at the bend radius and on all four short sides as shown in Figure 9d.

426 Again due to the pressure from the concrete core, the crushed areas were pushed outwards.

427 Having said this, data was lost for Specimen C-0 and the exact fracture load and ultimate 428 displacement at this load could not be accurately obtained. Therefore, for the ductility 429 calculations the ultimate displacement was based on $80 \%$ of the maximum load as done for 430 the steel reinforced specimen. Upon observation of the GFRP encased specimens after 431 testing, the stirrups at the welded locations were still intact and there were no signs of strength reductions at the overlap region. In fact, no failure of the stirrups was evident and the

433 GFRP sections failed first. Based on this, the welded steel stirrups in the encased specimens 434 served their purpose and did not affect the behavior of the encased specimens as failure of the 435 GFRP sections occurred first.

\section{Behavior of Column Specimens under 25 mm Eccentric Loading}

437 A specimen from each group was subjected to $25 \mathrm{~mm}$ of eccentric loading. The experimental 438 results of the $25 \mathrm{~mm}$ eccentricity loaded column specimens are summarized in Table 6 with 439 the axial and lateral load-displacement curves shown in Figure 10. Initially Specimen RS-25, 440 I-25 and C-25 experienced similar behavior before reaching maximum load. However, the 441 slope of the load-displacement curve of Specimen RF-25 was lower than that of the other 442 specimens. This could be due to errors in aligning the specimen resulting in load not being 443 applied exactly at $25 \mathrm{~mm}$ eccentricity. The first maximum load $\left(\mathrm{P}_{\max }\right)$ of the Specimens RS44425 , I-25 and C-25 were approximately equal. However, a decrease in first maximum load of 19.3\% relative to Specimen RS-25 was achieved for Specimen RF-25.

446 The cracking appearance of the specimens at failure in the tension and compression zones is 447 shown in Figure 11. Similar to the concentrically loaded specimens, stress concentrations on 448 the top of the specimens at the transition between the rounded corners and square edges 
449 produced stress concentrations resulting in cracks first appearing in those locations. As 450 testing progressed, the cracks propagated to all four sides of the specimen and to the 451 instrumented region. The application of the eccentric load resulted in the bending of the 452 specimens with one side of the specimen under compression and the other under tension. 453 After the maximum load the concrete in compression started to spall, with horizontal tension 454 cracks originating on the tension side of the specimens. As the load increased the concrete in compression completely spalled off, tension cracks increased and all the specimens failed in compression.

After the maximum load was achieved, the specimens lost a percentage of their maximum capacity due to the sudden spalling of the concrete cover in the compression zone. Specimen RS-25 lost approximately $13 \%$ of its maximum value, whereas the Specimen RF-25 lost 460 about $9 \%$ of the maximum load. After this drop in the capacity the load carrying capacity of 461 Specimen RS-25 gradually decreased until the eventual termination of the test occurred when 462 the load reached $35 \%$ of the maximum load. Specimen RS-25 displaced both axially and 463 laterally the most out of all the specimens, with no sudden failure in the steel occurring providing a good ductile behavior. On termination of the test it was realized that the two longitudinal steel bars on the compression side had substantially buckled as shown in Figure

$46611 \mathrm{~b}$ depicting the failure of the specimens in the compression side. Furthermore, the tension 467 cracks at mid-height of the specimen had grown substantially as shown in Figure 11a.

468 On the other hand, Specimen RF-25 was able to sustain an increase in load after the sudden 469 concrete spalling and eventually a second peak load ( $\left.\mathrm{P}_{\text {peak }}\right)$ of $823 \mathrm{kN}$ was achieved at an 470 axial ultimate displacement of $8.21 \mathrm{~mm}\left(\delta_{\mathrm{u}}\right)$. After this point, the load decreased at a high rate 471 until the eventual brittle and explosive failure of the internal reinforcement in compression at 472 a load of $353 \mathrm{kN}$ and axial displacement of $19.4 \mathrm{~mm}$. On observation, after this failure, both a 
473 longitudinal bar had fractured and a tie at the bend portion had ruptured on the compression 474 region at the top third of the specimen. It was unclear whether the bar or tie failed first and 475 whether the fracture of the bar was due to crushing or buckling (see Figure 12). Quickly 476 followed after, another tie at the bend portion and the other longitudinal bar failed in a similar 477 manner on the compression side with another drop in the load occurring. Unlike Specimen 478 RS-25, the failure region of Specimen RF-25 was at the top of the specimen which is not in 479 the instrumented region as shown in Figure 12. In addition, the large tension cracks also 480 developed at the top of the specimen rather than at mid-height, with concrete spalling also 481 occurring in tension as seen in Figure 11a. The reason for this as mentioned above may be 482 due to the stress concentrations at the top of the specimen due to the transition of the rounded 483 and sharp edges. Furthermore, another reason is the fracture of the compression bars resulted 484 in these bars not being able to carry anymore load resulting in the top of the specimen bowing 485 towards the compression region. The longitudinal bars in tension did not fail. After termination of the test it was evident that the crushing of concrete core occurred at the top of 487 the specimen. Considering, the unpredictable failure of the GFRP reinforcement after peak 488 load, the ultimate displacement for the ductility definition was taken as the axial displacement 489 at peak load rather than at a higher displacement corresponding to $80 \%$ of the peak load.

490 Although the peak load of Specimen RF-25 $(803 \mathrm{kN})$ was substantially lower than that of 491 Specimen RS-25 (995 kN), the ductility of both specimens was calculated to be 492 approximately similar based on the ductility definition in the above section with the steel 493 reinforced column obtaining a slightly higher ductility. Having said this, the eventual failure 494 of Specimen RF-25 was brittle and explosive with the load dropping substantially after peak 495 load unlike that of Specimen RS-25 which did not fail abruptly but continued to displace and 496 sustain the load until the termination of the test. 
497 Specimens I-25 and C-25 did not displace laterally or axially as much as Specimens RS-25 498 and RF-25. After the maximum load, the load of Specimen I-25 slightly dropped and then 499 increased up until a second peak load of $1024 \mathrm{kN}$ at which sudden failure occurred $\left(\mathrm{P}_{\text {peak }}\right.$ 500 equals $\left.\mathrm{P}_{\text {fracture }}\right)$. The failure was marked by the crushing and delamination of the compression 501 flange of the I-section at mid-height. The failure mode of the I-sections was similar to that of 502 the concentrically loaded specimen but only occurred in the compression flange. The concrete had not completely spalled at this point but just after the fracture load the concrete in compression was broken apart explosively at mid-height. Similarly, Specimen C-25 failed due to the crushing and rupture of the C-sections in the compression region. Interestingly 506 though after the maximum load was achieved, the load did not decrease suddenly as 507 experienced by the other specimens but instead the load stabilised until a load of $948 \mathrm{kN}$ at 508 which the failure of the C-sections occurred in compression due to material crushing and delaminating. After the fracture point there was a sudden drop in the load with a second drop 510 occurring not long after due to the failure of another section of the C-section. The ultimate 511 displacement of the GFRP encased specimens was taken at the fracture load. After the failure

512 load of the GFRP encased specimens was achieved, testing continued until the load reached $51335 \%$ of the first maximum load. After observation, it was realised that the tension cracking patterns of the GFRP encased specimens was different to the reference specimens as shown in Figure 11a. These vertical cracks seem to originate at the edges of the sections which could

516 potentially mean inadequate confinement to the concrete core which results in the concrete 517 cover spalling similar to that of concentrically loaded columns. In addition to tensile cracks it 518 is observed that the concrete cover in the tensile region spalled off, which was marked by the vertical cracks. Similar to the concentrically loaded specimens, the GFRP encased specimens showed little ductile behavior after the maximum load was reached as compared to the other two specimens. Specimen C-25experienced a slightly higher ductility than that of Specimen 
522 I-25, which may be as a result of the confinement provided by the box arrangement of the internal C-sections

\section{Behavior of Column Specimens under 50 mm Eccentric Loading}

525 A specimen from each group was subjected to $50 \mathrm{~mm}$ of eccentric loading. The experimental results of the $50 \mathrm{~mm}$ eccentrically loaded specimens are summarized in Table 7 with the axial and lateral load-displacement curves shown in Figure 13. Similar to the $25 \mathrm{~mm}$ eccentrically loaded specimens, the specimens experienced similar behavior before reaching the maximum load. The maximum load for Specimen RS-50 was obtained to be $747 \mathrm{kN}$ and experienced good ductility. A decrease of first maximum load of $17.7 \%$ relative to Specimen RS-50 was achieved for Specimen RF-50. Unlike the other loading cases, Specimen C-50 obtained a lower maximum load as compared to Specimen RS-50. On the other hand, Specimen I-50 experienced a slight increase in maximum load with reference to Specimen RS-0 but experienced low ductility with failure occurring slightly after the maximum load. In addition, Specimen RF-50 experienced a second peak load, with the load carrying capacity increasing after the sudden spalling of the concrete cover. After this point the load substantially decreased until the eventual failure of the GFRP bars in compression at a load of $374 \mathrm{kN}$ and axial displacement of $13.61 \mathrm{~mm}$. After this failure point the specimen could not carry any more load. In terms of ductility and based on the definitions in the above section, the

540 Specimen RF-50 shows a slight improvement in ductility as compared to Specimen RS-50.

541 Furthermore, although the ductility values of the GFRP encased specimens show a reasonable

542 value for ductility, failure was sudden and brittle as opposed to that of Specimen RS-50.

543 Similar to the $25 \mathrm{~mm}$ eccentric loading condition, Specimens I-50 and C-50 did not displace 544 laterally or axially as much as the reference specimens. 
545 The failure of the specimens was also observed to be in compression, similar to the failure 546 mechanisms of the $25 \mathrm{~mm}$ eccentricity loaded specimens. During or after concrete spalling in

547 the compression side, the steel reinforcement on the compression side buckled and the two

548 GFRP longitudinal bars crushed and explosively fractured, while the reinforcement in tension

549 did not fail. Again due to stress concentrations at the transition of the sharp and round edges,

550 the failure of Specimen RF-50 was at the top of the specimen with the two longitudinal bars

551 completely crushing and separating with no notable rupture in the stirrups (see Figure 14).

552 The tension cracks were larger on the top of the specimen (Figure 14a) with severe crushing 553 of concrete occurring on the top of the specimen at the fracture location of the bars 554 throughout the cross-section in both compression and tension, as shown in Figure 14b and 555 14c. The CFRP tension strengthening strips were also debonded form the concrete (see 556 Figure 14a).

557 Sudden failure of the I-section occurred for Specimen I-50 at a second peak load of $769 \mathrm{kN}$ 558 after the maximum load was achieved. The failure mode of the I-sections was similar to that 559 of the $25 \mathrm{~mm}$ eccentrically loaded specimen which was marked by the crushing and 560 delamination of the compression flange at mid-height Similarly, Specimen C-25 failed due to 561 the crushing and rupture of the C-sections in the compression region. Although the failure 562 load for Specimen C-25 of $695 \mathrm{kN}$ was lower than that for Specimen I-50 of $769 \mathrm{kN}$, the 563 ductility of the C-section encased specimen (3.29) was greater than that of the I-section encased specimen (2.30) which proves the benefits of the confinement mechanism of the Csections. Furthermore, the cracking appearance on the tension side of the specimens at the 566 end of testing was similar to that of the $25 \mathrm{~mm}$ eccentrically loaded specimen with concrete 567 cover appearing to be spalled on the GFRP encased specimens. The GFRP sections in the tension side did not appear to fail during testing. 
570 The last specimen from each group was tested as a beam under four-point loading. The load 571 versus midspan deflection of the beam specimens are shown in Figure 15. The first specimen 572 tested was Specimen RS-B. Due to a malfunction in the data logger, the midspan deflections 573 obtained from the laser triangulation were lost. Therefore, the midspan deflection for 574 Specimen RS-B was recorded from the readings of the testing machine, with a maximum 575 load of $232 \mathrm{kN}$ achieved at a midspan deflection of $8.1 \mathrm{~mm}$. After the maximum load was reached, the load was maintained until sudden failure occurred in the tension region of the specimen, at a midspan defection of $20.1 \mathrm{~mm}$. The failure was typical flexural failure with

578 large tension cracks evident at the midspan of the specimen with considerable crushing of the 579 concrete in the compression zone occuring.

580 The second beam specimen tested was Specimen I-B. At the early stages of loading, bearing 581 failure occurred at the two ends of the specimen with concrete crushing at the two supports, 582 as shown in Figure 16 after testing was terminated. This can be seen from the slight drop and then increase in load on the load versus midspan deflection curve. As a result of this initial bearing failure mode, a lower than expected maximum load of $215.7 \mathrm{kN}$ was obtained at a midspan deflection of $13.47 \mathrm{~mm}$. The test was terminated prematurely due to human errors in setting up the safety precautions of the test. The third specimen tested was Specimen C-B. To

587 ensure no bearing failure occurred, a $50 \mathrm{~mm}$ wide by $8 \mathrm{~mm}$ thick steel plate was placed as a bearing plate on the two supports. In addition, as added precaution the two ends of the specimen, at $100 \mathrm{~mm}$ length, were wrapped with two layers of CFRP wrap as shown in

590 Figure 17. Specimen C-B achieved the highest maximum load of all the specimens, with a 591 load of $370 \mathrm{kN}$ obtained at a midspan deflection of $12.78 \mathrm{~mm}$. Therefore, Specimen C-B 592 achieved an increase of $59.5 \%$ in maximum load as compared to Specimen RS-B. At the maximum load there was a drop in the load-deflection curve. After this point, small cracking 
594 noises were heard and subsequent drops in the curve occurred due to possible failure of the

595 C-sections at different areas, as shown in Figure 15.

596 The last beam specimen tested was Specimen RF-B. Two beams reinforced with GFRP bars

597 were prepared, with one acting as spare. The first beam tested failed in shear and errors in

598 testing occurred with unreliable results. To increase the shear capacity the second beam

599 specimen reinforced with GFRP bars was wrapped with two layers of CFRP at the shear

600 zones at the outer thirds of the specimen with the specimen unwrapped between the two point

601 loads. Again steel bearing plates were provided at the supports. The load-midspan deflection

602 response was almost linear up until a maximum load of $340.3 \mathrm{kN}$ at a midspan deflection of

$60312.13 \mathrm{~mm}$. At the maximum load the first rupture of the CFRP sheets resulted in a sudden

604 decrease in load. The specimen then still resisted the load under increasing deflection until

605 the second peak load was achieved. Another rupture of the CFRP sheet resulted in a drop of

606 the load. After several ruptures, the bearing plate had shifted as a result of the roller on the

607 supports. The slippage of the bearing plates resulted in the plate being wedged under the

608 specimen and explains the behavior after midspan deflections of $20 \mathrm{~mm}$ where no eventual

609 failure occurred in the internal reinforcement of the specimen and the load plateaued out with

610 the test terminated not long after. The addition of the bearing plates would have resulted in

611 slippage at the connection with the pin and roller supports which would have had an impact

612 on the mid-span deflections and load carried. For the purposes of this study these slippages

613 were ignored. By observation, the failure of the steel reinforced specimen was a typical

614 flexural failure. However, the GFRP reinforced and GFRP encased specimens appear to have

615 failed in shear rather than in flexure even though the GFRP reinforced specimen (RF-B) was

616 wrapped with two layers of CFRP in the shear zone. It is unclear whether the steel reinforced

617 specimen would have experienced an increase in load carrying capacity if the steel bearing 
618 pads and ends of the specimen were wrapped with CFRP, which was done for the other beam

619 specimens.

620 The initial stiffnesses of all the beams were different as shown in Figure 15. Possible reasons

621 for these differences are that some beams were provided with a bearing pad (Group C and

622 RF) while others were not. Other reasons may be the wrapping of the Group RF specimen

623 resulted in a change in the load-midspan behavior with respect to the other specimens or the

624 small ratio of the shear span to depth ratio of the specimens resulted in inconsistency in

625 testing. Therefore, the ductility of the beam specimens were not determined and analysed.

\section{Conclusion}

627 A total of 16 square specimens, twelve as columns and four as beams, were tested in this 628 study to investigate the type of internal reinforcement (steel bars, GFRP bars and encased 629 GFRP strucutral sections) and magnitude of load eccentricity on the compressive and flexural 630 behavior of concrete specimens. Based on the experimental results of this study, the 631 following conclusions were drawn:

632 1. The column specimens of Group RS achieved a higher load carrying capacity as compared 633 to the column specimens of Group RF for all loading conditions. The load carrying capacity 634 of the Group RF column specimen loaded concentrically (RF-0) was $4.8 \%$ lower than its 635 steel counterpart. On the other hand, the load carrying capacity of the Group RF column 636 specimens loaded eccentrically (RF-25 and RF-50) were on average $18.5 \%$ lower than their 637 steel counterparts. Therefore, a higher drop in load carrying capacity was experienced for the 638 eccentrically loaded GFRP reinforced column specimens with respect to the equivalent steel 639 reinforced column specimens. 
640 2. For concentrically loaded columns, the column specimens of Group RS achieved a better

641 ductile perfomance compared to the column specimens of Group RF. For eccentric loading

642 conditions, column specimens of Group RF achieved similar ductility as compared to the

643 column specimens of Group RS, based on the ductility definition in the paper. However, the

644 eventual failure mechanism of the GFRP reinforced column specimens was brittle and sudden

645 in nature, whereas the steel reinforced column specimens did not fail abruptly but continued

646 to displace until the termination of the test.

647 3. The GFRP encased column specimens achieved a higher load carrying capacity but lower 648 ductility as compared to the other reference column specimens. Group C column specimens 649 experienced better ductility to that of Group I column specimens which is attributed to the 650 confinement effect of the C-sections box arrangement. Having said this, the Group I column 651 specimens achieved a slightly higher load carrying capacity as compared to the Group C 652 column specimens.

653 4. Based on the results of the beam specimens the use of encased GFRP structural sections 654 can provide a significant improvement in the load carrying capacity when comparing 655 conventional beams reinforced with steel and GFRP bars. There is potential in encasing 656 structural GFRP sections in concrete beams although further research elaboration is necessary 657 to investigate this considering some of the errors and premature failure mechanisms 658 experienced in the experiemental program of the beam specimens.

\section{Acknowledgments}

660 The authors would like to acknowledge the technical assistance of Messrs Alan Grant,

661 Fernando Escribano, Richard Gasser, Cameron Neilson, Duncan Best and Ritchie McLean.

662 The contribution of Ms. Philippa Langford is greatly appreciated. The second author would like to thank the University of Wollongong for the support of his Ph.D. scholarship. 
ACI (American Concrete Institute). (2006). "Guide for the Design and Construction of

Afifi, M. Z., Mohamed, H. M., and Benmokrane, B. (2014). "Axial Capacity of Circular 668 Concrete Columns Reinforced with GFRP Bars and Spirals." Journal of Composites for Construction, 10.1061/(ASCE)CC.1943-5614.0000438, 04013017-1-04013017-11.

670 ASTM. (2002). "Standard test method for compressive properties of rigid plastics." D695, West Conshohocken, PA.

672 ASTM. (2011). "Standard test method for tensile properties of fiber reinforced polymer matrix composite bars." ASTM D7205-11, West Conshocken, PA, USA

674 Benmokrane, B., Chaallal, O., and Masmoudi, R. (1996). "Flexural Response of Concrete 675 Beams Reinforced with FRP Reinforcing Bars" ACI Structural Journal, 93(1), 46-55

676 Correia, J. R., Branco, F.A., and Ferreira, J. (2009). "GFRP-concrete hybrid cross-sections 677 for floors of buildings." Engineering Structures, 31(6), 1331-1343.

678 Correia, M., Nunes, F., Correia, J., and Silvestre, N. (2013). "Buckling Behavior and Failure 679 of Hybrid Fiber-Reinforced Polymer Pultruded Short Columns." Journal of Composites for 680 Construction, 17(4), 463-475.

681 CSA (Canadian Standards Association). (2012). "Design and Construction of Building 682 Structures with Fiber-Reinforced Polymers." CAN/CSA S806-12, Toronto, Canada

683 De Luca, A., Matta, F., and Nanni, A. (2010). "Behavior of Full-Scale Glass Fiber684 Reinforced Polymer Reinforced Concrete Columns under Axial Load." ACI Structural 685 Journal, 107(05), 589-596.

686 Ehsani, M. R., Saadatmanesh, H., and Tao, S. (1995). "Bond of Hooked Glass Fiber 687 Reinforced Plastic (GFRP) Reinforcing Bars to Concrete." ACI Materials Journal, 92 (4), $688 \quad 391-400$.

689 GRP (n.d). Brisbane, Australia, www.grpaustralia.com.au

690 Hadi, M. N. S. (2006). "Behavior of FRP wrapped normal strength concrete columns under 691 eccentric loading" Composite Structures, 72(4), 503-511

692 Hadi, M. N. S., and Widiarsa, I. B. R. (2012). "Axial and Flexural Performance of Square RC 693 Columns Wrapped with CFRP under Eccentric Loading." Journal of Composites for 694 Construction, 16(6), 640-649. 
695 Hadi, M. N. S., Karim, H., and Sheikh, M. Neaz. (2015). "Experimental Investigations on

696 Circular Concrete Columns Reinforced with GFRP Bars and Helices under Different Loading

697 Conditions." Journal of Composites for Construction, in press.

698 ISO. (1997). "Determination of tensile properties of plastics. Part 4: Test conditions for 699 isotropic and orthotropic fibre-reinforced plastic composites." ISO 527-4, European 700 Committee for Standardisation, Brussels, Belgium.

701 Issa, M.S., Metwally, I.M., and Elzeiny, S.M. (2011). "Structural performance of 702 Eccentrically loaded GFRP Reinforced concrete columns." International Journal of Civil and 703 Structural Engineering, 2(1), 395-406.

704 Kwan, W. H., and Ramli, M. (2013). "Indicative performance of fiber reinforced polymer 705 (FRP) encased beam in flexure." Construction and Building Materials, 48(0), 780-788.

706 Mohamed, H.M., Afifi, M.Z., and Benmokrane, B. (2014). "Performance Evaluation of 707 Concrete Columns Reinforced Longitudinally with FRP Bars and Confined with FRP Hoops 708 and Spirals under Axial Load." Journal of Bridge Engineering, 10.1061/(ASCE)BE.1943709 5592.0000590, 04014020-1- 04014020-12.

710 Ozbakkaloglu, T. (2013). "Axial Compressive Behavior of Square and Rectangular High711 Strength Concrete-Filled FRP Tubes." Journal of Composites for Construction,17(1), 151712161.

713 Pessiki, S., and Pieroni, A. (1997). "Axial load behavior of large-scale spirally-reinforced 714 high-strength concrete columns." ACI Structural Journal, 94(3), 304-313

715 Pultrall, Inc. (2012). V-ROD - Specification HM, Thetford Mines, Canada, www.pultrall.com

716 Sheikh, M. Neaz., and Legeron, F. (2014). "Performance based seismic assessment of bridges 717 designed according to Canadian Highway Bridge Design Code." Canadian Journal of Civil 718 Engineering, 41 (9), 777-787

719 Standards Australia. (1999). "Methods of testing concrete - Method 9: Determination of the 720 compressive strength of concrete specimens." AS1012.9-1999, Sydney, Australia

721 Standards Australia. (2007). "Metallic materials - Tensile testing at ambient temperatures." 722 AS1391-2007, Sydney, Australia Standards Australia. (2009). "Concrete Structures." 723 AS3600-2009, Sydney, Australia

724 Thériault, M., and Benmokrane, B. (1998). "Effects of FRP Reinforcement Ratio and 725 Concrete Strength on Flexural Behavior of Concrete Beams." Journal of Composites for 726 Construction, 2(1), 7-16

727 Tobbi, H., Farghaly, A. S., and Benmokrane, B. (2012). "Concrete Columns Reinforced 728 Longitudinally and Transversally with Glass Fiber-Reinforced Polymer Bars." ACI Structural 729 Journal, 109(4), 551-558. 
730 Warner, R.F., Foster, S.J., and Kilpatrick, A.E. (2007). Reinforced Concrete Basics - Analyis 731 and design of reinforced concrete structures, Pearson, Sydney, Australia.

732 Xue, W., Hu, X., and Fang, Z. (2014). "Experimental studies of GFRP Reinforced Concrete 733 Columns under Static Eccentric Loading." Proc., 7th International Conference on FRP

734 Composites in Civil Engineering (CICE 2014), International Institute for FRP in 735 Construction, Vancouver, Canada 
737 Figure 1. Plan view of reinforcement details for all groups of specimens

738 Figure 2. Geometry of stirrups (a) Steel stirrups in Group RS Specimens; (b) GFRP stirrups 739 in Group RF Specimens

740 Figure 3. Completed reinforcement cages: (a) Side-view ; (b) Cross-sections

741 Figure 4. Sand coating of the GFRP structural encased sections

742 Figure 5. Eccentric loading setup: (a) Loading system; (b) Eccentric loading heads; and (c)

743 Interaction of eccentric loading heads

$744 \quad$ Figure 6. Typical flexural testing setup

745 Figure 7. Axial load-deflection curves of the concentrically loaded column specimens, $746 \mathrm{e}=0 \mathrm{~mm}$

747 Figure 8. Overview of concentrically loaded specimens after failure

748 Figure 9. Close-up view of the failure modes of concentrically tested columns: (a) Specimen 749 RS-0; (b) Specimen RF-0; (c) Specimens I-0; and (d) Specimen C-0

750 Figure 10. Axial and lateral load-deflection curves of the $25 \mathrm{~mm}$ eccentrically loaded column 751 specimens, $\mathrm{e}=25 \mathrm{~mm}$

752 Figure 11. Failure modes of the $25 \mathrm{~mm}$ eccentrically loaded column specimens: (a) Tension 753 side; (b) Compression side

754 Figure 12. Failure mode Specimen RF-25

755 Figure 13. Axial and lateral load-deflection curves of the $50 \mathrm{~mm}$ eccentrically loaded column 756 specimens, $\mathrm{e}=50 \mathrm{~mm}$

757 Figure 14. Failure mode Specimen RF-50: (a) Tension side; (b) Side-view; and (c) Crushing 758 of compression bars

759 Figure 15. Load-midspan deflection curves of the beam specimens

760 Figure 16. Bearing failure of Specimen I-B

761 Figure 17. Measures to prevent beaing failure of beam specimens 
762 List of Tables

763 Table 1. Experimental Test Matrix

764 Table 2. Tensile Properties of the Steel Bars

765 Table 3. Tensile Properties of the GFRP Bars (averages and sample standard deviations)

766 Table 4. Tensile and compressive properties of the GFRP pultruded structural sections

767 (averages and sample standard deviations)

768 Table 5. Experiment results of column specimens tested under concentric loading

769 Table 6. Results of column specimens tested under $25 \mathrm{~mm}$ eccentric loading

770 Table 7. Results of column specimens tested under $50 \mathrm{~mm}$ eccentric loading 
Table 1. Experimental Test Matrix

\begin{tabular}{|c|c|c|c|c|c|c|c|c|c|c|c|}
\hline \multirow[b]{2}{*}{ Group } & \multirow{2}{*}{$\begin{array}{c}\text { Test } \\
\text { Specimen }\end{array}$} & \multicolumn{4}{|c|}{ Longitudinal Reinforcement } & \multicolumn{3}{|c|}{ Transverse Reinforcement } & \multicolumn{2}{|c|}{ Encased Sections } & \multirow{2}{*}{$\begin{array}{c}\text { Test } \\
\text { Eccentricity } \\
(\mathrm{mm})\end{array}$} \\
\hline & & Material & $\begin{array}{l}\text { Number } \\
\text { of bars }\end{array}$ & $\begin{array}{c}\text { Diameter } \\
(\mathrm{mm})\end{array}$ & $\begin{array}{c}\text { Reinforcement } \\
\text { Ratio }(\%)\end{array}$ & Material & $\begin{array}{c}\text { Diameter } \\
(\mathrm{mm})\end{array}$ & $\begin{array}{c}\text { Spacing } \\
(\mathrm{mm})\end{array}$ & Material & Type & \\
\hline \multirow[t]{4}{*}{1} & RS-0 & Steel & 4 & 12 & 1.03 & Steel & 10 & 50 & - & - & 0 \\
\hline & $\mathrm{RS}-25$ & & & & & & & & & & 25 \\
\hline & RS-50 & & & & & & & & & & 50 \\
\hline & RS-B & & & & & & & & & & Bending \\
\hline \multirow[t]{4}{*}{2} & $\mathrm{RF}-0$ & GFRP & 4 & 12.7 & 1.15 & GFRP & 9.5 & 50 & - & - & 0 \\
\hline & RF-25 & & & & & & & & & & 25 \\
\hline & RF-50 & & & & & & & & & & 50 \\
\hline & RF-B & & & & & & & & & & Bending \\
\hline \multirow[t]{4}{*}{3} & $\mathrm{I}-0$ & - & - & - & - & Steel & 10 & 100 & GFRP & I-section & 0 \\
\hline & $\mathrm{I}-25$ & & & & & & & & & & 25 \\
\hline & $\mathrm{I}-50$ & & & & & & & & & & 50 \\
\hline & I-B & & & & & & & & & & Bending \\
\hline \multirow[t]{4}{*}{4} & $\mathrm{C}-0$ & - & - & - & - & Steel & 10 & 100 & GFRP & C-sections & 0 \\
\hline & $\mathrm{C}-25$ & & & & & & & & & & 25 \\
\hline & $\mathrm{C}-50$ & & & & & & & & & & 50 \\
\hline & C-B & & & & & & & & & & Bending \\
\hline
\end{tabular}


772 Table 2. Tensile Properties of the Steel Bars

\begin{tabular}{cccccc}
\hline Bar & Reinforcement & $\begin{array}{c}\text { Average tensile } \\
(\mathrm{mm})\end{array}$ & $\begin{array}{c}\text { Average tensile } \\
\text { yield strain } \\
\mathrm{f}_{\mathrm{y}}(\mathrm{MPa})\end{array}$ & $\begin{array}{c}\text { Average tensile } \\
\varepsilon_{\mathrm{y}}(\%)\end{array}$ & $\begin{array}{c}\text { modulus, } \\
\mathrm{E}(\mathrm{GPa})^{\mathrm{a}}\end{array}$ \\
\hline R10 & Transverse & 10 & $326^{\mathrm{b}}$ & $0.370^{\mathrm{b}}$ & 191.7 \\
$\mathrm{~N} 12$ & Longitudinal & 12 & 540 & 0.324 & 199.8 \\
\hline
\end{tabular}

$773{ }^{\mathrm{a}}$ Calculated as the slope of the elastic linear region of the stress-strain relationship.

$774 \quad{ }^{\mathrm{b}}$ Determined by the $0.2 \%$ Offset Method 
775 Table 3. Tensile Properties of the GFRP Bars (averages and sample standard deviations)

\begin{tabular}{|c|c|c|c|c|c|c|}
\hline Bar Size & $\begin{array}{l}\text { Nominal } \\
\text { Diameter } \\
(\mathrm{mm})\end{array}$ & $\begin{array}{l}\text { Standard cross- } \\
\text { sectional Area } \\
\left(\mathrm{mm}^{2}\right)\end{array}$ & $\begin{array}{c}\text { Cross-sectional } \\
\text { area by Immersion } \\
\text { Test }\left(\mathrm{mm}^{2}\right)^{\mathrm{a}}\end{array}$ & $\begin{array}{c}\text { Tensile strength, } \\
\mathrm{f}_{\mathrm{fu}}(\mathrm{MPa})^{\mathrm{b}}\end{array}$ & $\begin{array}{c}\text { Tensile rupture } \\
\text { strain, } \\
\varepsilon_{\mathrm{f}}(\%)^{\mathrm{b}}\end{array}$ & $\begin{array}{c}\text { Tensile } \\
\text { modulus, } \\
\mathrm{E}(\mathrm{GPa})^{\mathrm{b}, \mathrm{c}}\end{array}$ \\
\hline$\# 3$ & 9.5 & 70.9 & 134.9 & $1855 \pm 60$ & $2.39 \pm 0.12$ & $77.6 \pm 1.1$ \\
\hline$\# 4$ & 12.7 & 126.7 & 190.7 & $1641 \pm 73$ & $2.41 \pm 0.10$ & $67.9 \pm 1.3$ \\
\hline
\end{tabular}

${ }^{\mathrm{a}}$ Determined in accordance with ASTM D7205-06 (2011)

$777{ }^{\mathrm{b}}$ The material properties calculated are based on the bars standard cross-sectional area determined by the nominal diameter.

$778{ }^{\mathrm{c}}$ Calculated as the slope of the elastic linear region of the stress-strain relationship. 
779 Table 4. Tensile and compressive properties of the GFRP pultruded structural sections (averages and sample standard deviations)

\begin{tabular}{cccc}
\hline Property & I-section - WEB & I-section - FLANGE & C-section \\
Longitudinal & Longitudinal & Longitudinal \\
\hline Tensile Strength $(\mathrm{MPa})$ & $386.5 \pm 17.4$ & $430.2 \pm 32.7$ & $318.1 \pm 31.8$ \\
Tensile Modulus $(\mathrm{GPa})$ & $20.7 \pm 0.7$ & $26.0 \pm 2.2$ & $26.2 \pm 2.0$ \\
Tensile Rupture Strain $(\%)$ & $1.94 \pm 0.08$ & $1.75 \pm 0.17$ & $1.22 \pm 0.11$ \\
Compressive Strength $(\mathrm{MPa})^{\mathrm{a}}$ & $213.1 \pm 27.6$ & $236.9 \pm 28.5$ & $304.9 \pm 80.1$ \\
Compressive Modulus $(\mathrm{GPa})$ & $22.3 \pm 2.2$ & $25.1 \pm 3.1$ & $25.0 \pm 2.7$ \\
Compressive Rupture Strain $(\%)^{\mathrm{a}}$ & - & - & -
\end{tabular}

$780 \quad{ }^{\mathrm{a}}$ Bearing failure occurred at top and bottom of coupon tested in compression resulting in potential premature failure. See Material Properties 781 section. 
782 Table 5. Experiment results of column specimens tested under concentric loading

\begin{tabular}{ccccccccc}
\hline Test & Max. & Axial & Yield & Axial & Fracture & Ultimate & Ductility & Ductility \\
Specimen & Load & displ. at & Load & displ. At & Load & Displ. & $\begin{array}{c}\text { Method } \\
\text { Method }\end{array}$ & $\begin{array}{c}\mathrm{P}^{\mathrm{d}} \\
\end{array}$ \\
& $\mathrm{P}_{\max }(\mathrm{kN})$ & $\mathrm{P}_{\max }$ & $\mathrm{P}_{\text {yield }}$ & $\mathrm{P}_{\text {yield }}$ & $\mathrm{P}_{\text {fracture }}$ & $\delta_{\mathrm{u}}(\mathrm{mm})$ & $1^{\mathrm{d}}$ & $2^{\mathrm{d}}$ \\
& & $(\mathrm{mm})$ & $(\mathrm{kN})$ & $\delta_{\mathrm{y}}(\mathrm{mm})$ & $(\mathrm{kN})$ & & & \\
\hline RS-0 & 1350 & 2.87 & 1122 & 1.68 & - & $15.24^{\mathrm{a}}$ & 9.07 & 16.80 \\
RF-0 & 1285 & 2.59 & 1089 & 1.58 & 1126 & $7.72^{\mathrm{b}}$ & 4.89 & 8.37 \\
$\mathrm{I}-0$ & 1425 & 3.13 & 1173 & 1.86 & 1258 & $4.65^{\mathrm{b}}$ & 2.50 & 3.98 \\
$\mathrm{C}-0$ & 1385 & 3.24 & 1199 & 2.27 & $-^{\mathrm{c}}$ & $7.33^{\mathrm{c}}$ & 3.23 & 5.19 \\
\hline
\end{tabular}

$783{ }^{\mathrm{a}}$ The displacement at the $80 \%$ of $\mathrm{P}_{\max }$

$784{ }^{\mathrm{b}}$ The displacement at the fracture of the GFRP reinforcement

$785{ }^{\mathrm{c}}$ Data was lost and the fracture load of the GFRP C-section could not be obtained. Therefore the ultimate displacement was based on $80 \%$ of $786 \mathrm{P}_{\max }$, although failure did occur before this point but could not be accurately determined.

787 d Refer to section "Behavior of Column Specimens" for definitions of the methods 
789 Table 6. Results of column specimens tested under $25 \mathrm{~mm}$ eccentric loading

\begin{tabular}{|c|c|c|c|c|c|c|c|c|c|c|}
\hline $\begin{array}{c}\text { Test } \\
\text { Specimen }\end{array}$ & $\begin{array}{c}1^{\text {st }} \text { Max. } \\
\text { Load } \\
\mathrm{P}_{\max }(\mathrm{kN})\end{array}$ & $\begin{array}{c}\text { Axial } \\
\text { displ. at } \\
\mathrm{P}_{\max } \\
(\mathrm{mm})\end{array}$ & $\begin{array}{c}\text { Lateral } \\
\text { displ. At } \\
\mathrm{P}_{\max } \\
(\mathrm{mm})\end{array}$ & $\begin{array}{l}\text { Yield } \\
\text { Load } \\
\mathrm{P}_{\text {yield }} \\
(\mathrm{kN})\end{array}$ & $\begin{array}{c}\text { Axial } \\
\text { displ. At } \\
\mathrm{P}_{\text {yield }} \\
\delta_{y}(\mathrm{~mm})\end{array}$ & $\begin{array}{c}\text { Second } \\
\text { Peak } \\
\text { Load, } \\
P_{\text {peak }}(\mathrm{kN})\end{array}$ & $\begin{array}{c}\text { Fracture } \\
\text { Load } \\
\mathrm{P}_{\text {fracture }} \\
(\mathrm{kN})\end{array}$ & $\begin{array}{c}\text { Ultimate } \\
\text { Displ. } \\
\delta_{\mathrm{u}} \\
(\mathrm{mm})\end{array}$ & $\begin{array}{c}\text { Ductility } \\
\text { Method } \\
1^{\mathrm{d}}\end{array}$ & $\begin{array}{l}\text { Ductility } \\
\text { Method } \\
2^{\mathrm{d}}\end{array}$ \\
\hline RS-25 & 995 & 2.72 & 2.11 & 904 & 2.13 & - & - & $8.04^{\mathrm{a}}$ & 3.77 & 5.96 \\
\hline RF-25 & 803 & 3.00 & 2.27 & 701 & 2.20 & 823 & 353 & $8.21^{\mathrm{b}}$ & 3.62 & 6.10 \\
\hline $\mathrm{I}-25$ & 1008 & 2.51 & 2.05 & 905 & 2.00 & 1024 & 1024 & $4.97^{\mathrm{c}}$ & 2.49 & 3.96 \\
\hline C-25 & 985 & 2.86 & 2.96 & 866 & 2.03 & - & 948 & $5.68^{\mathrm{c}}$ & 2.80 & 4.65 \\
\hline
\end{tabular}

$790 \quad{ }^{\mathrm{a}}$ The displacement at the $80 \%$ of $\mathrm{P}_{\max }$

$791{ }^{\mathrm{b}}$ The displacement at $\mathrm{P}_{\text {peak }}$

$792{ }^{\mathrm{c}}$ The displacement at the first fracture of the GFRP reinforcement

793 d Refer to section "Behavior of Columns Specimens" for definitions of the methods 
794 Table 7. Results of column specimens tested under $50 \mathrm{~mm}$ eccentric loading

\begin{tabular}{|c|c|c|c|c|c|c|c|c|c|c|}
\hline $\begin{array}{c}\text { Test } \\
\text { Specimen }\end{array}$ & $\begin{array}{c}1^{\text {st }} \text { Max. } \\
\text { Load } \\
\mathrm{P}_{\max }(\mathrm{kN})\end{array}$ & $\begin{array}{c}\text { Axial } \\
\text { displ. at } \\
\mathrm{P}_{\max } \\
(\mathrm{mm})\end{array}$ & $\begin{array}{c}\text { Lateral } \\
\text { displ. At } \\
\mathrm{P}_{\max } \\
(\mathrm{mm})\end{array}$ & $\begin{array}{l}\text { Yield } \\
\text { Load } \\
\mathrm{P}_{\text {yield }} \\
(\mathrm{kN})\end{array}$ & $\begin{array}{c}\text { Axial } \\
\text { displ. At } \\
\mathrm{P}_{\text {yield }} \\
\delta_{\mathrm{y}}(\mathrm{mm})\end{array}$ & $\begin{array}{c}\text { Second } \\
\text { Peak } \\
\text { Load, } \\
P_{\text {peak }}(\mathrm{kN})\end{array}$ & $\begin{array}{c}\text { Fracture } \\
\text { Load } \\
\mathrm{P}_{\text {fracture }} \\
(\mathrm{kN})\end{array}$ & $\begin{array}{c}\text { Ultimate } \\
\text { Displ. } \\
\delta_{\mathrm{u}} \\
(\mathrm{mm})\end{array}$ & $\begin{array}{c}\text { Ductility } \\
\text { Method } \\
1^{\mathrm{d}}\end{array}$ & $\begin{array}{l}\text { Ductility } \\
\text { Method } \\
2^{\mathrm{d}}\end{array}$ \\
\hline RS-50 & 747 & 2.65 & 2.66 & 672 & 2.02 & - & - & $7.55^{\mathrm{a}}$ & 3.74 & 5.94 \\
\hline RF-50 & 615 & 2.33 & 2.46 & 558 & 1.77 & 626 & 374 & $9.44^{\mathrm{b}}$ & 5.33 & 9.44 \\
\hline I-50 & 765 & 2.88 & 3.18 & 688 & 2.19 & 769 & 769 & $5.04^{\mathrm{c}}$ & 2.30 & 3.56 \\
\hline C-50 & 679 & 3.04 & 3.69 & 607 & 2.08 & 695 & 695 & $6.84^{\mathrm{c}}$ & 3.29 & 5.67 \\
\hline
\end{tabular}

$795{ }^{\mathrm{a}}$ The displacement at the $80 \%$ of $\mathrm{P}_{\max }$

$796{ }^{\mathrm{b}}$ The displacement at $\mathrm{P}_{\text {peak }}$

$797{ }^{\mathrm{c}}$ The displacement at the first fracture of the GFRP reinforcement

798 d Refer to section "Behavior of Column Specimens" for definitions of the methods 


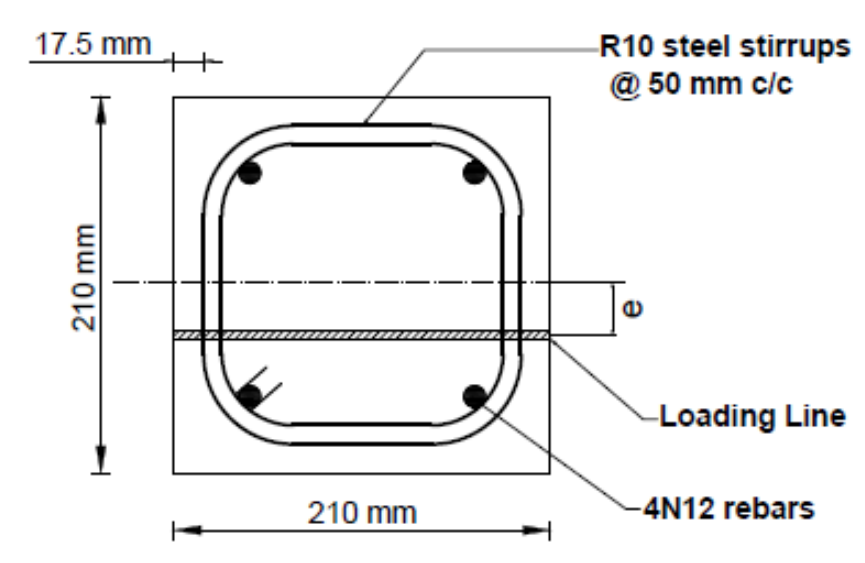

Group RS

(Reference Steel)

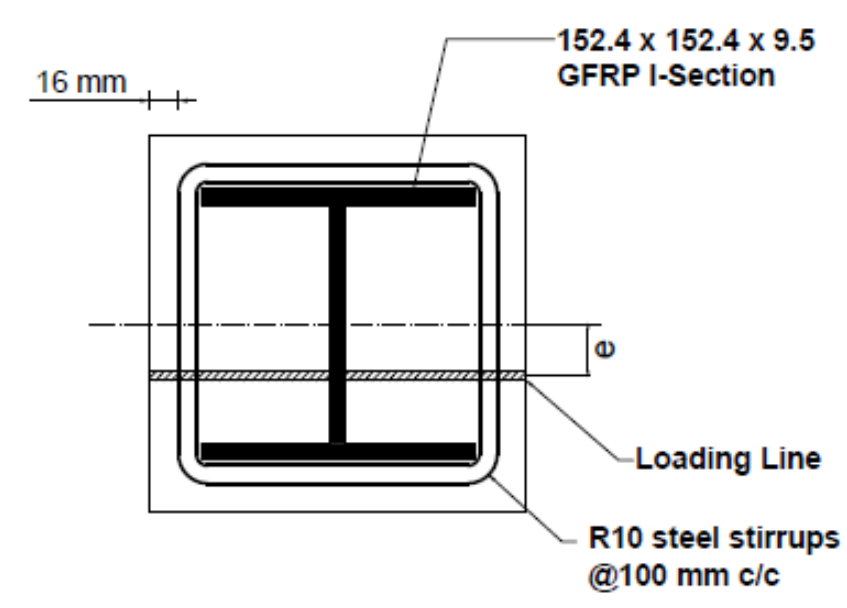

Group I

(I-section encased)

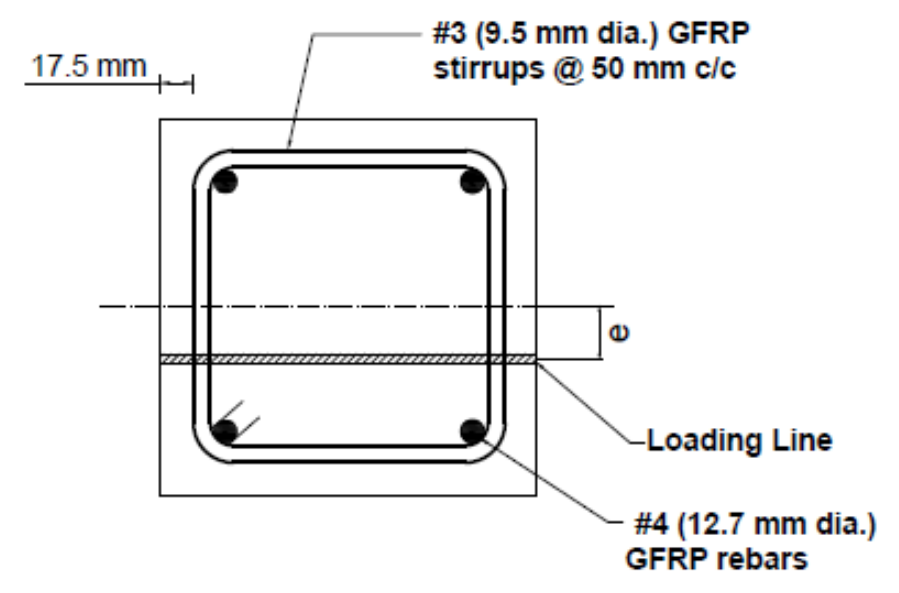

Group RF

(Reference GFRP)

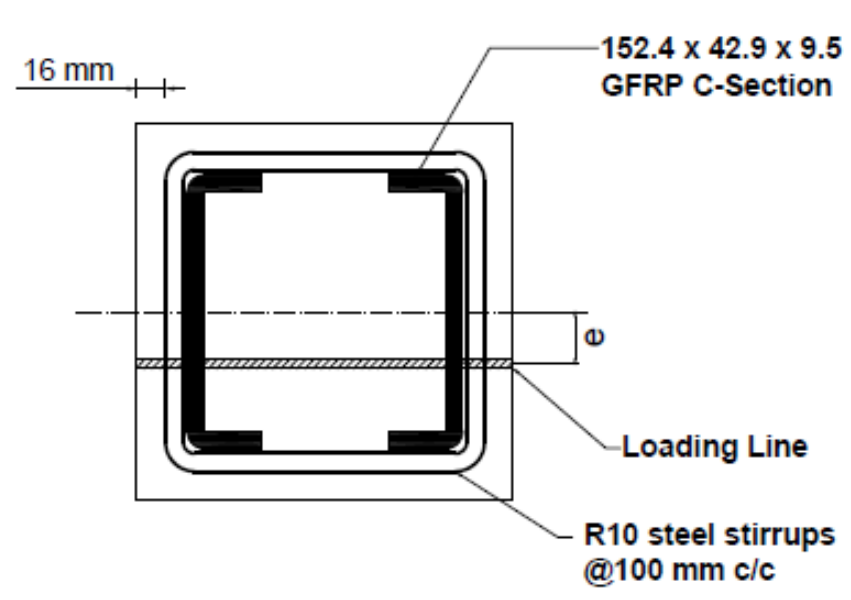

Group C

(C-section encased) 
Fig. 2
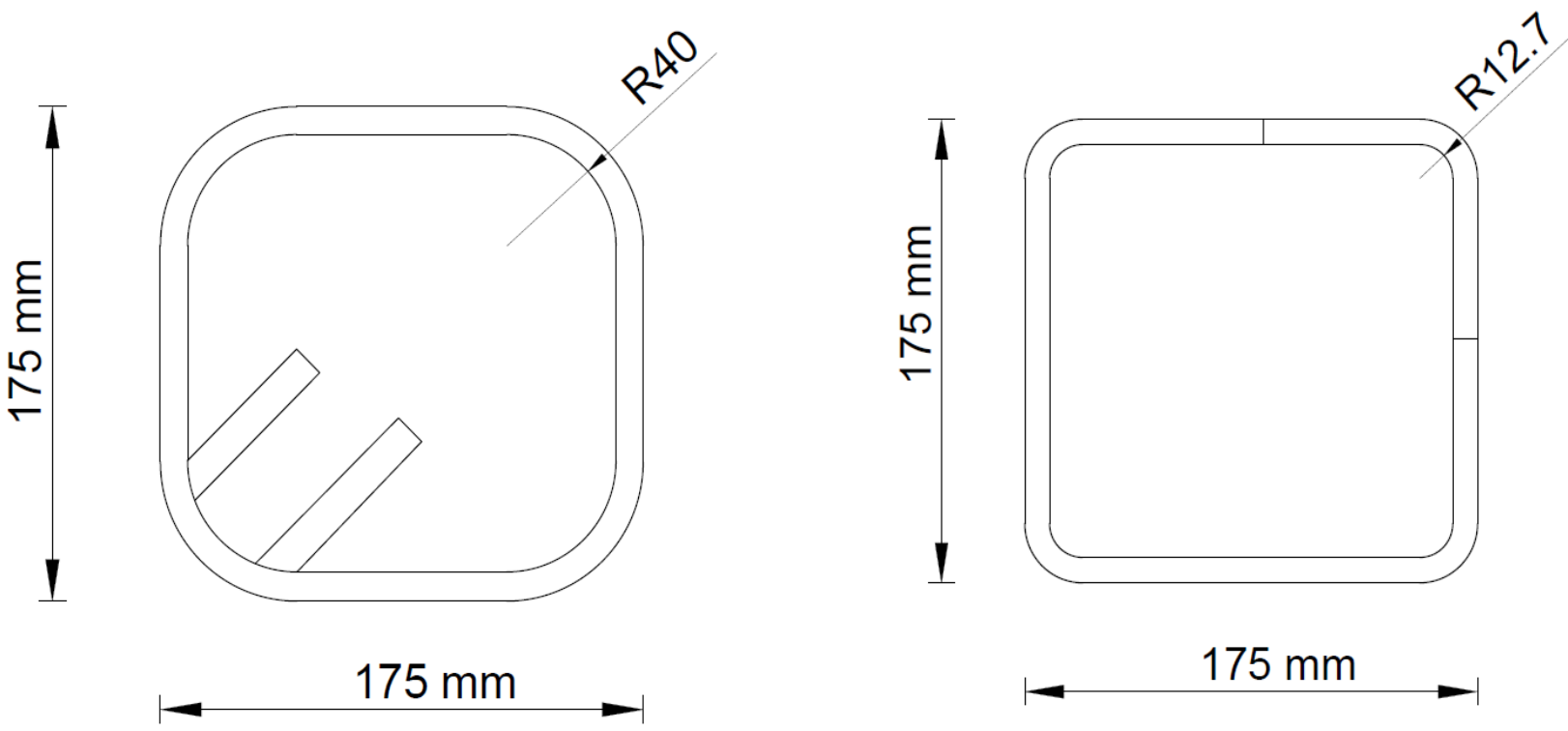

a) Steel stirrups in Group RS Specimens

b) GFRP stirrups in Group RF Specimens 
Fig. 3

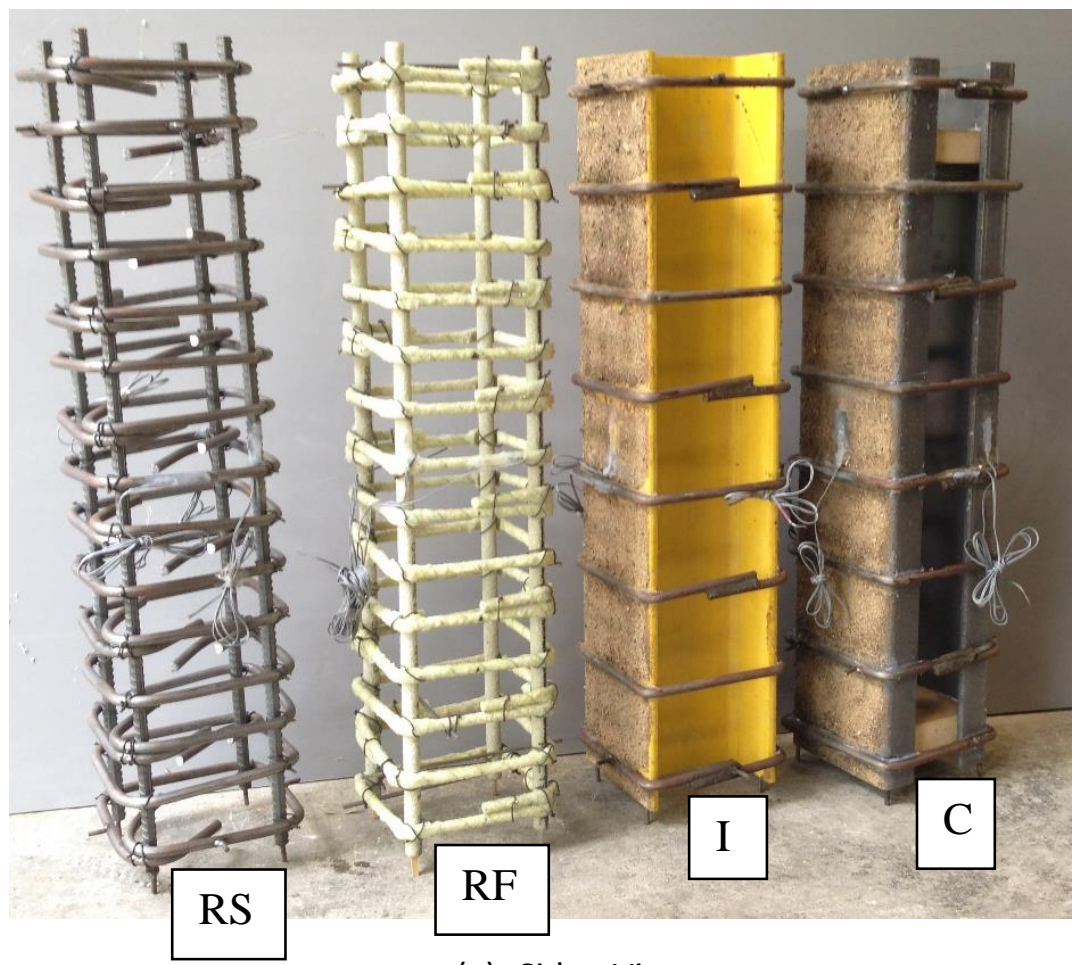

(a) Side - View

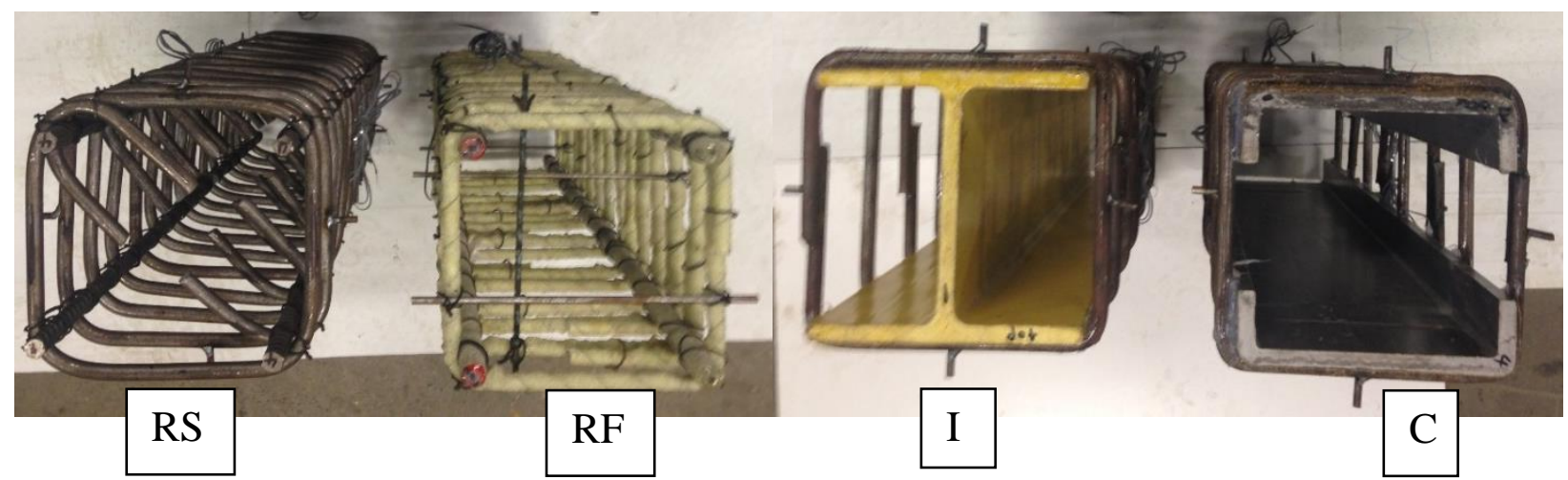

(b) Cross - sections 
Fig. 4
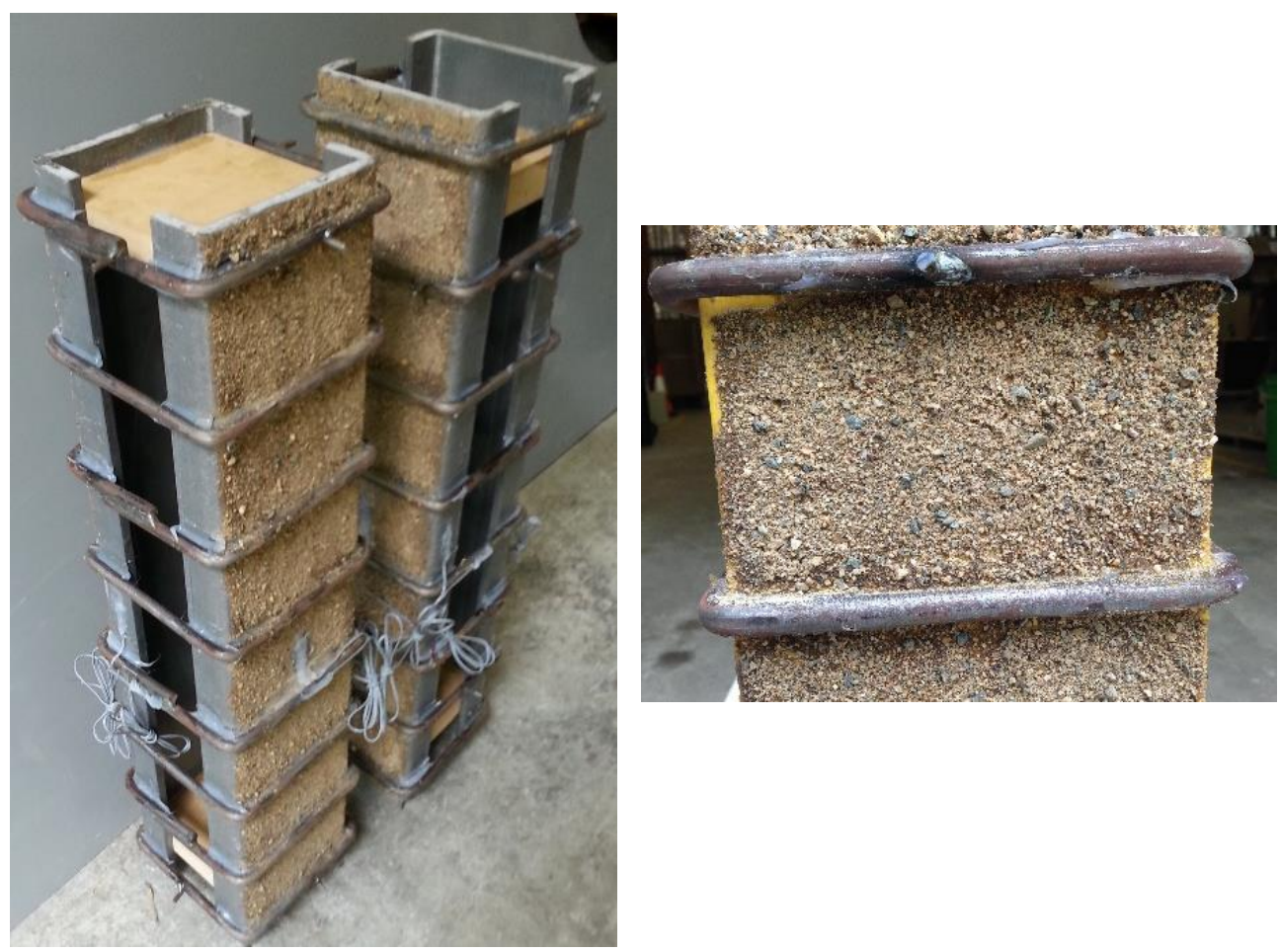
Fig.5

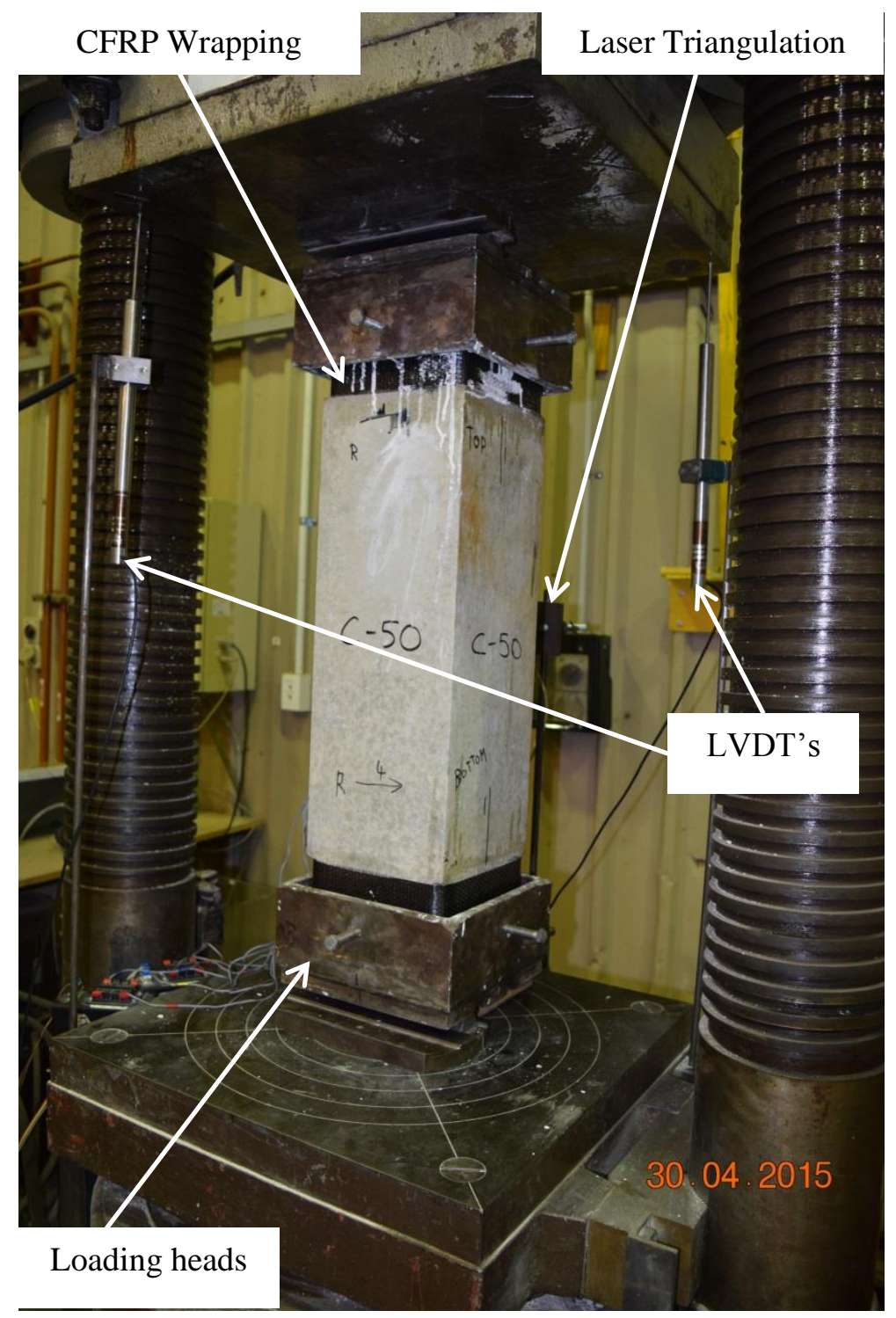

(a) Loading system

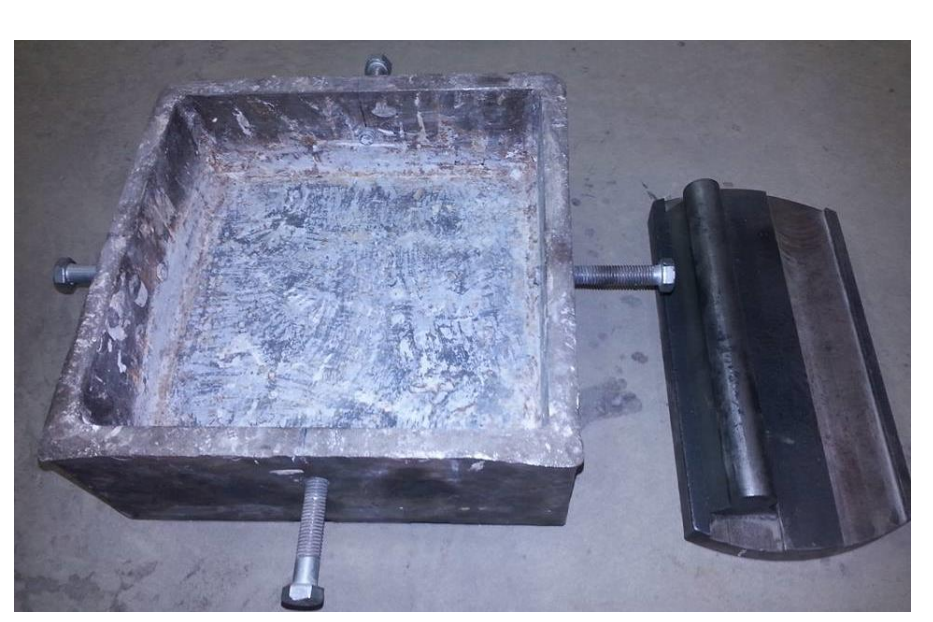

(b) Eccentric loading heads

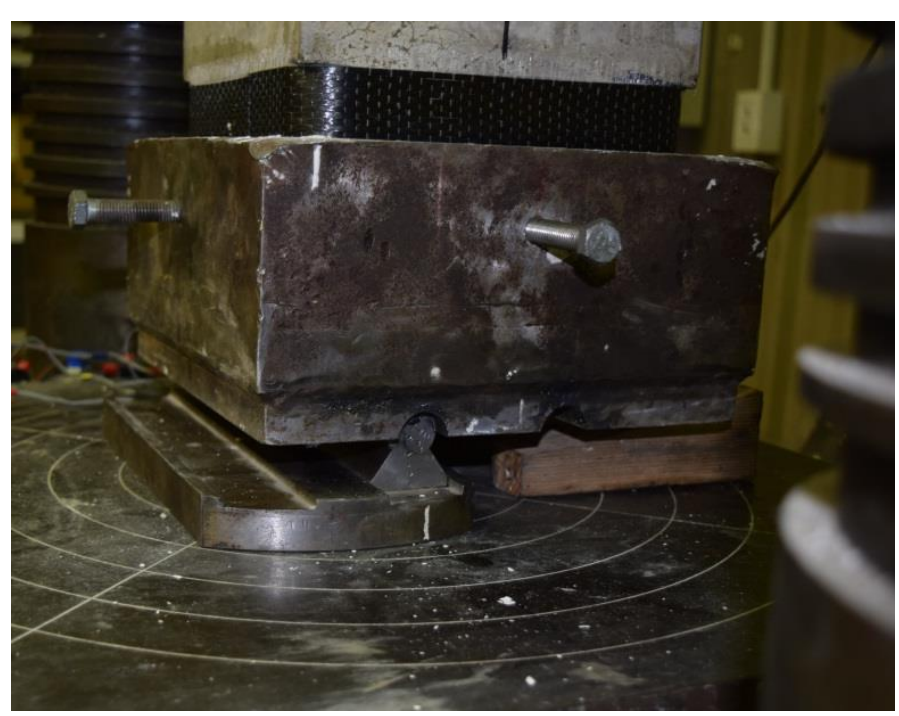

(c) Interaction of the eccentric loading heads 
Fig. 6

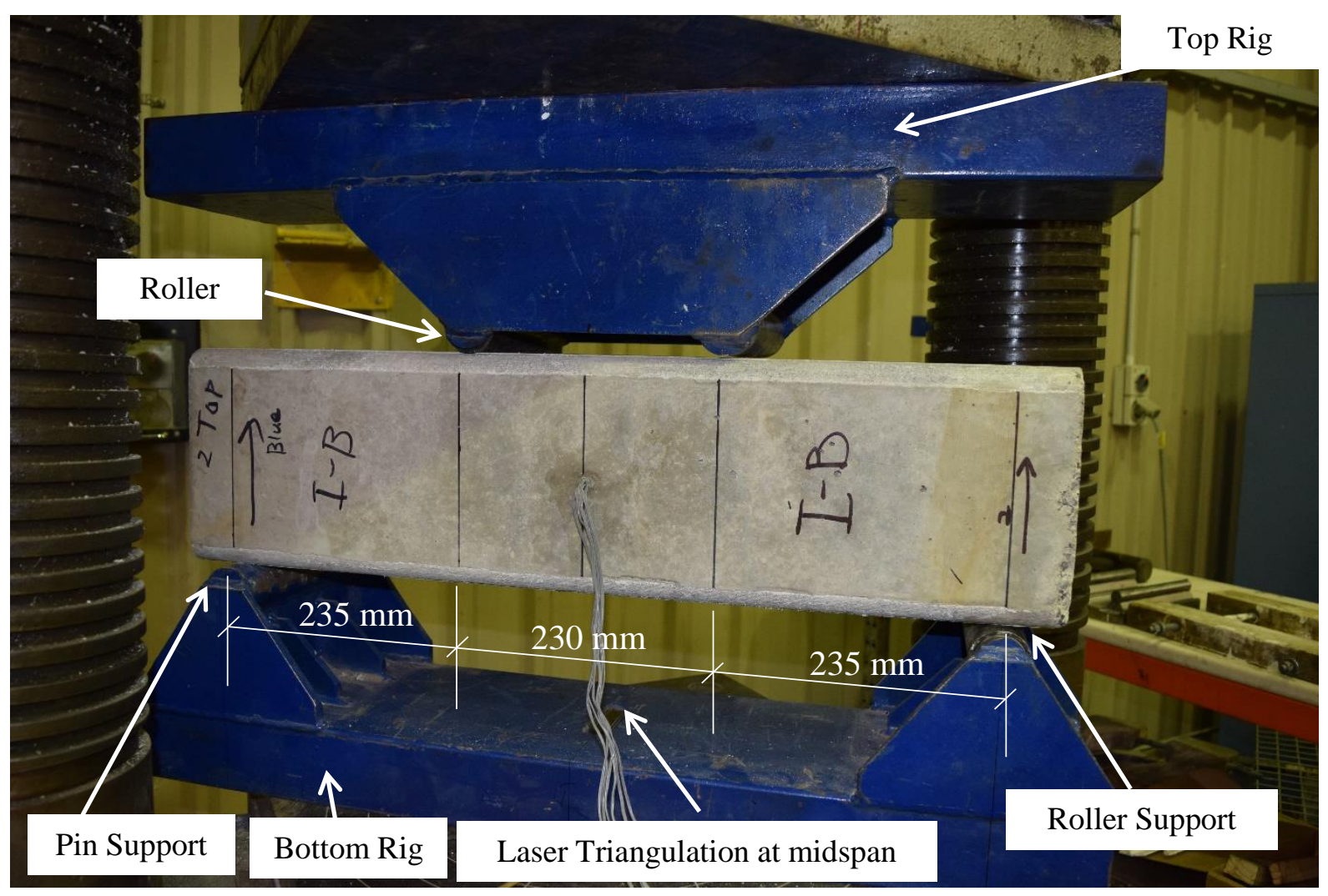


Fig. 7

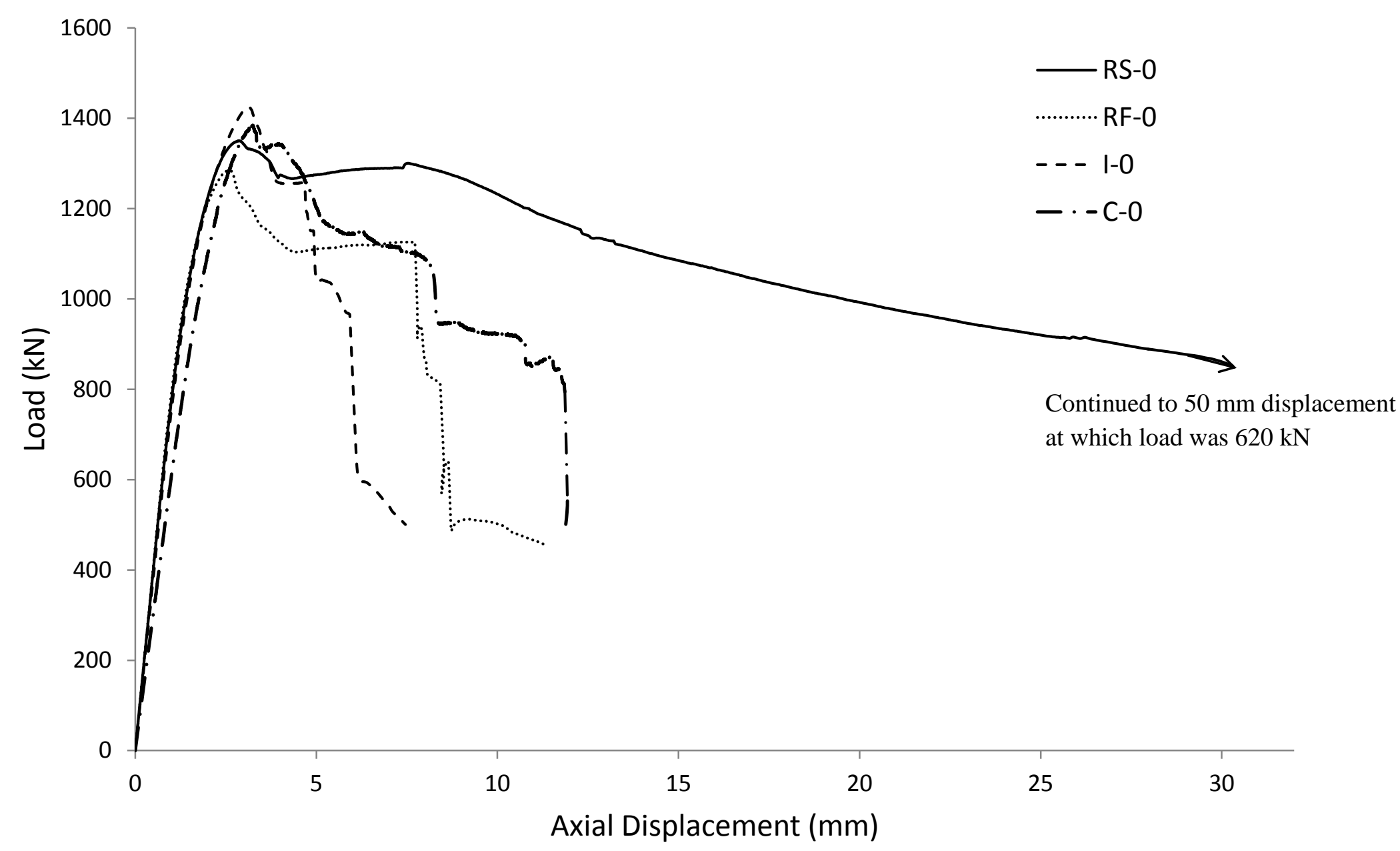




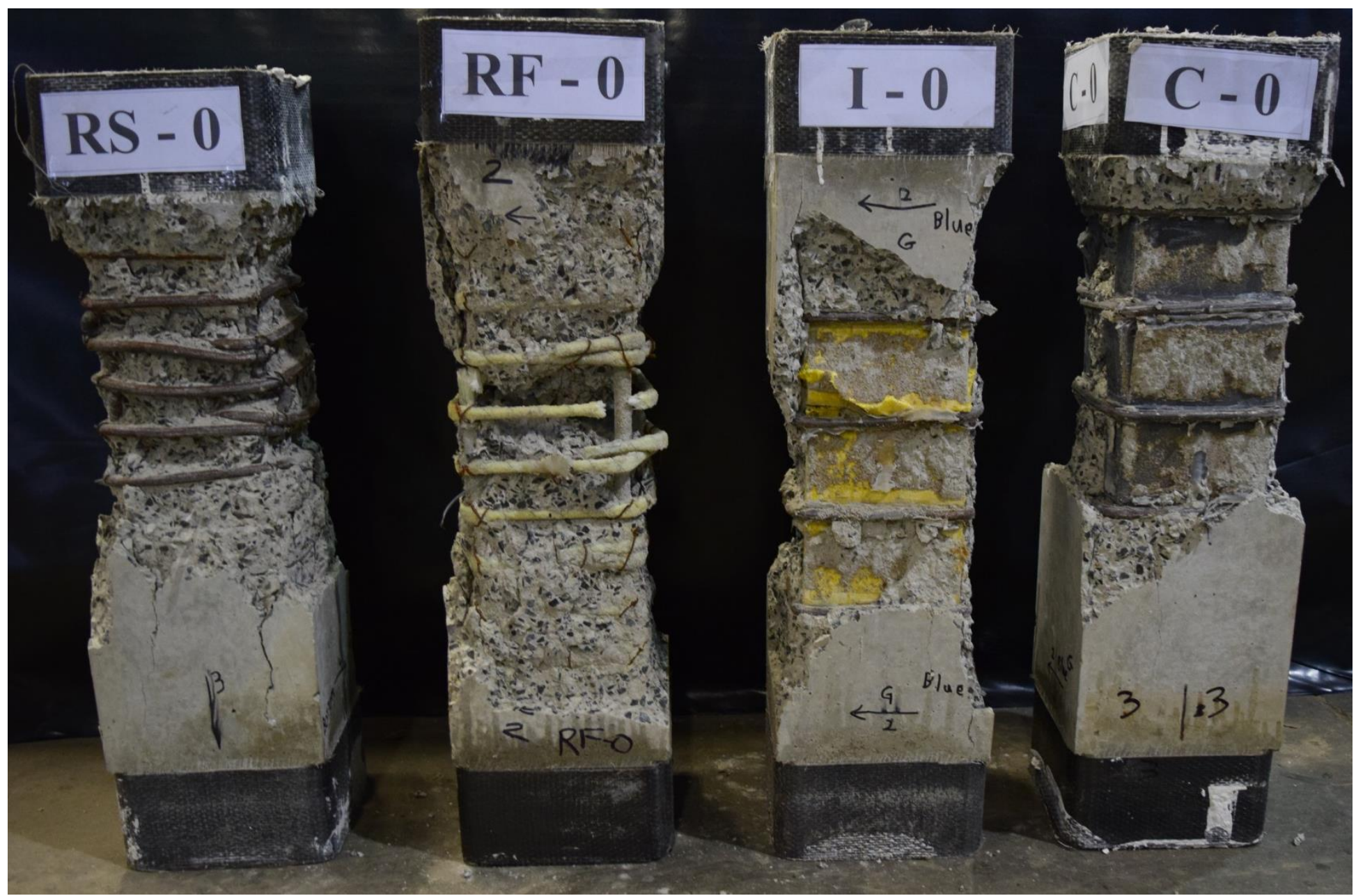


Fig. 9

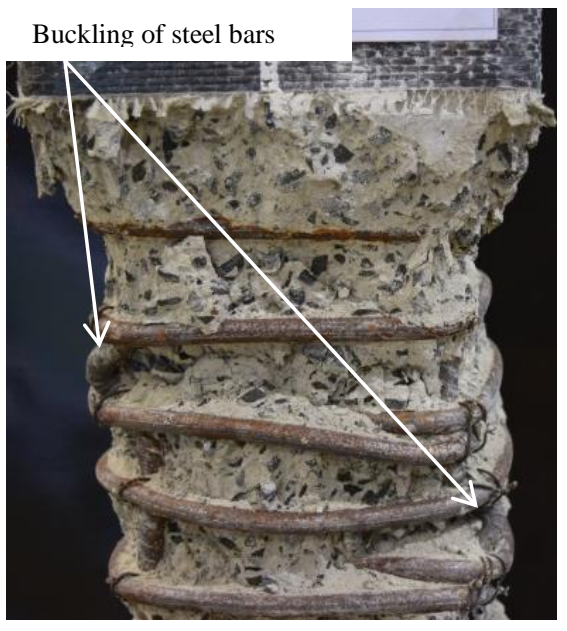

(a) Specimen RS-0
Crushing or potential buckling of all four GFRP bars followed by crushing of concrete core

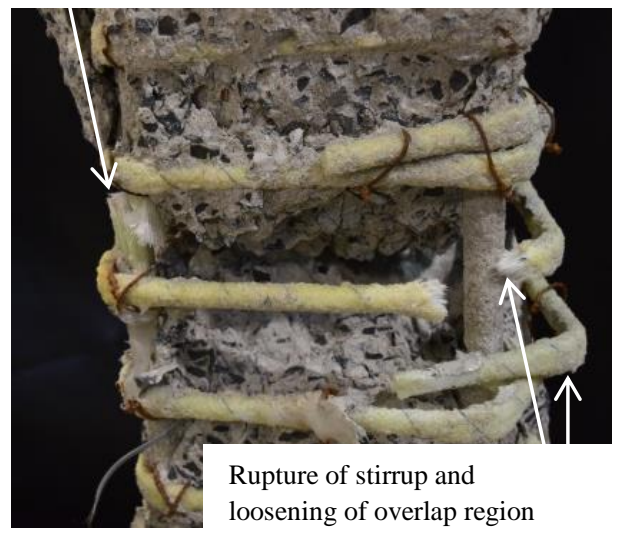

(b) Specimen RF-0

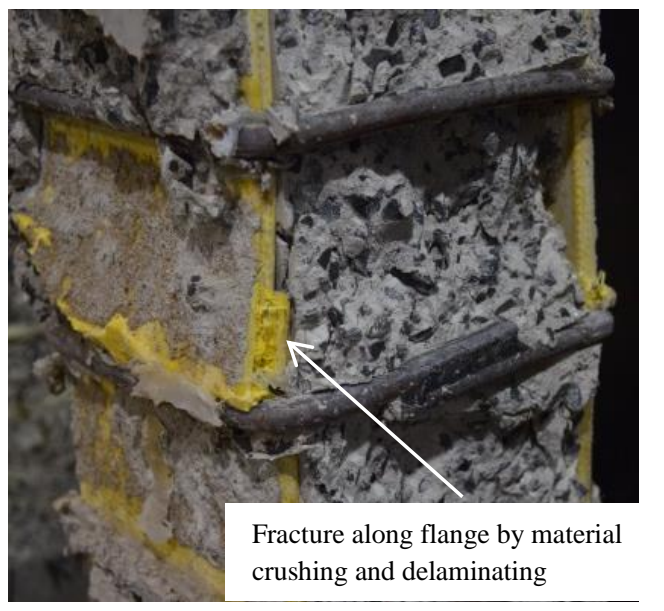

(c) Specimen I-0

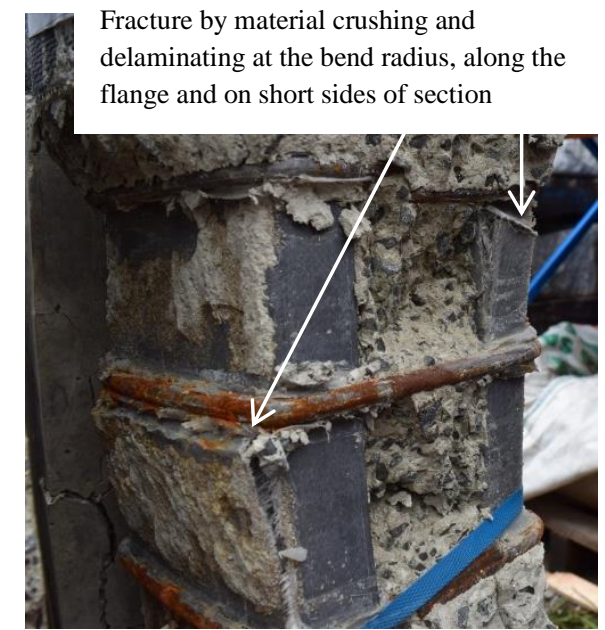

(d) Specimen C-O 
Fig. 10

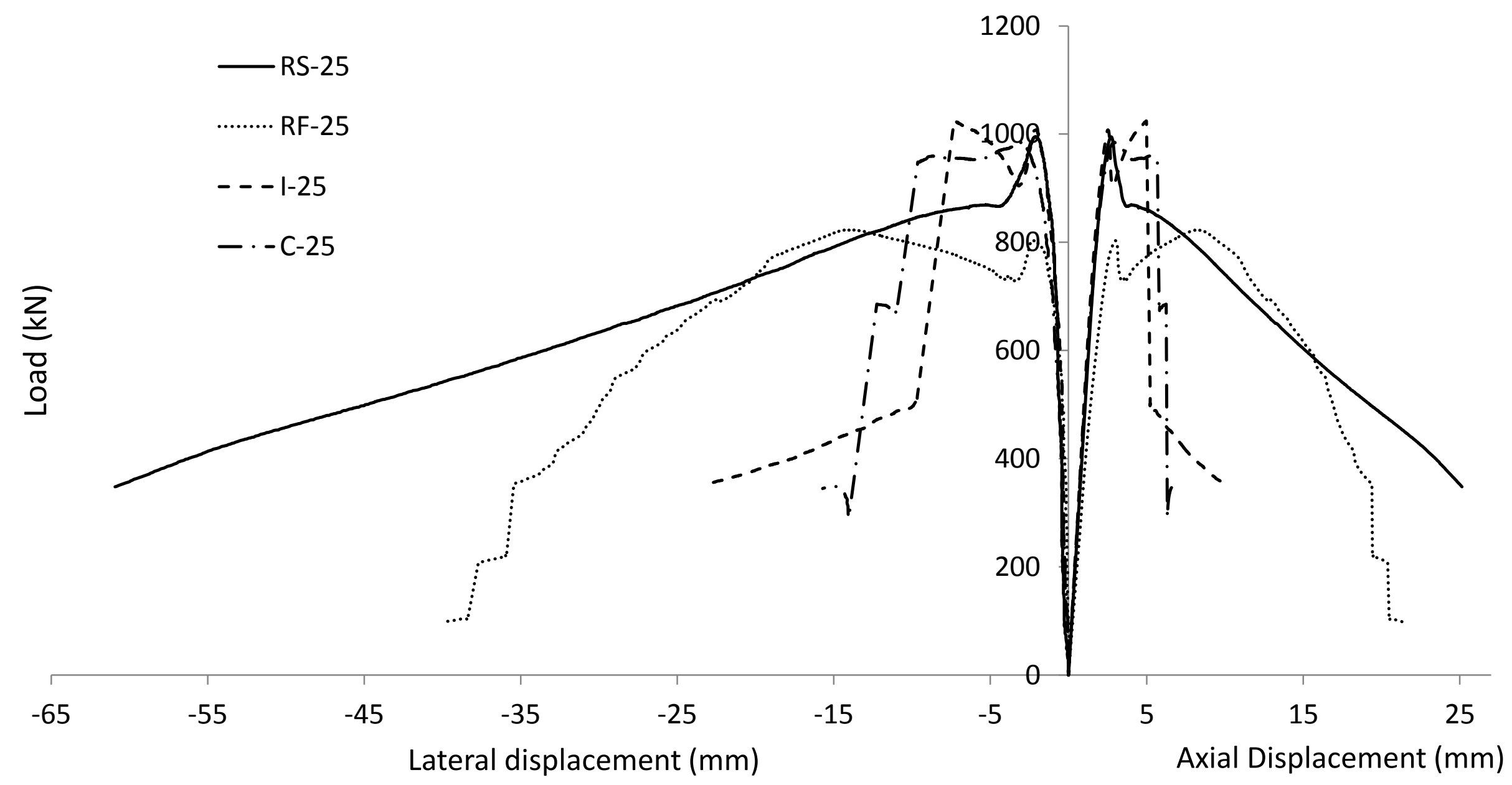


Fig. 11

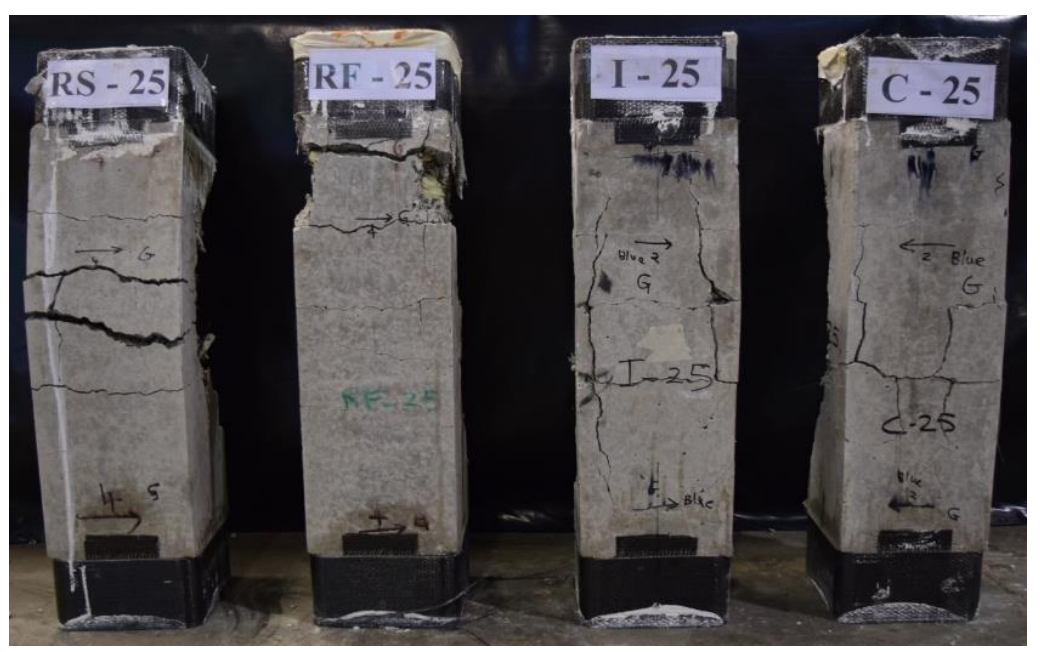

(a) Tension side

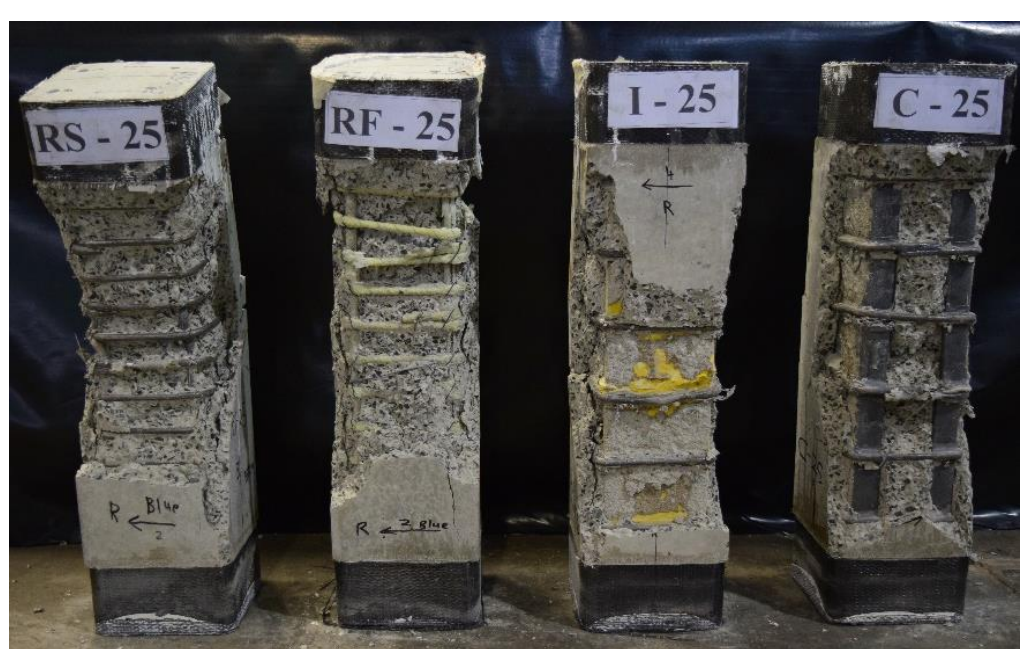

(b) Compression side 
Fig. 12

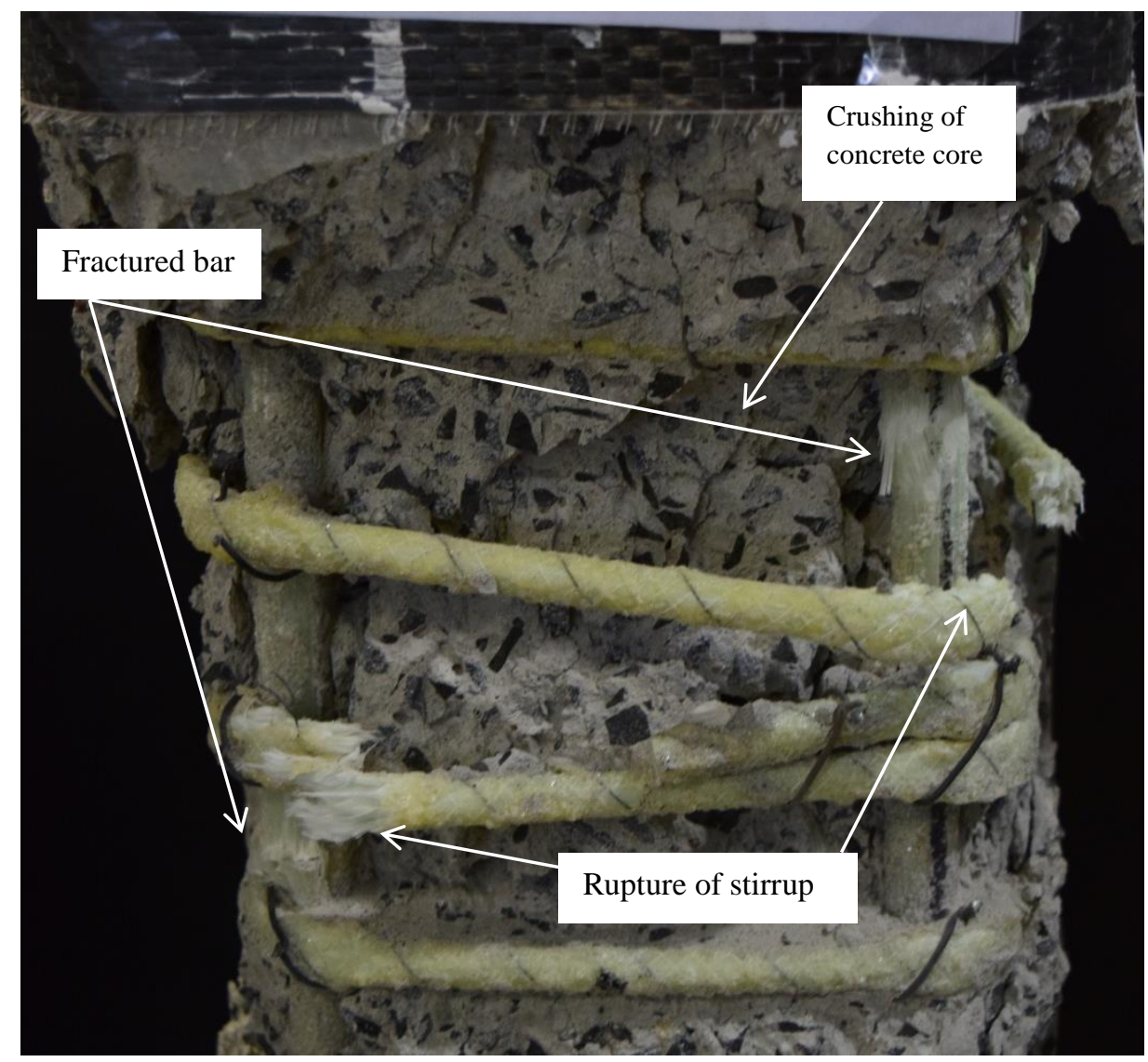


Fig. 13

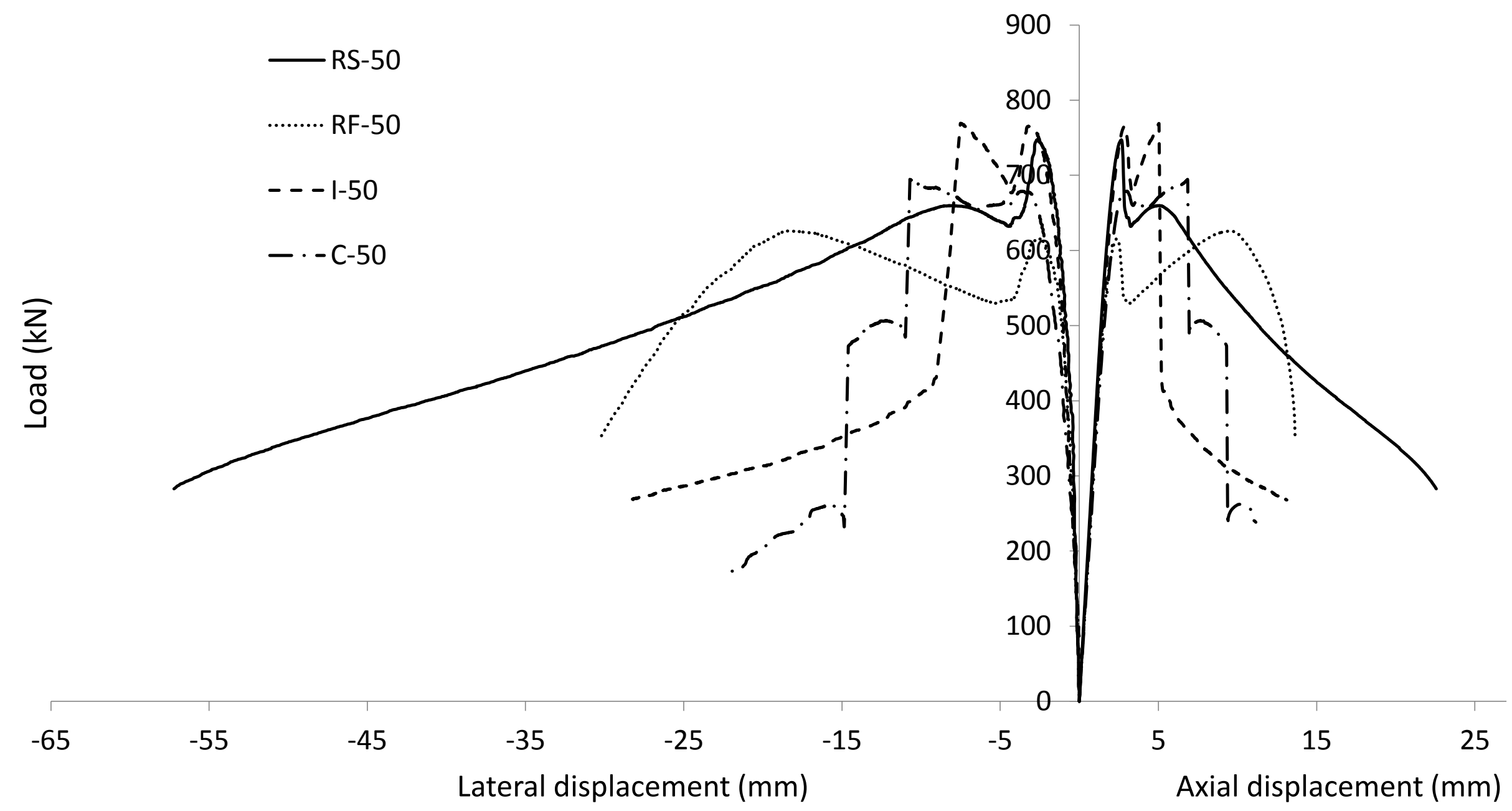


Fig. 14

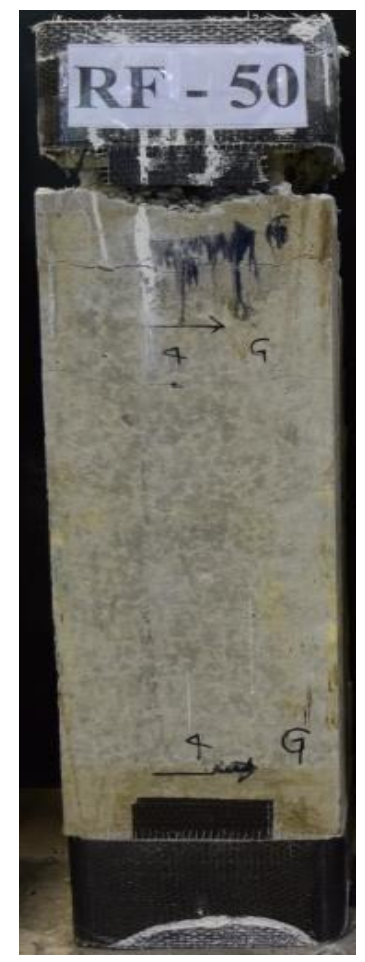

(a)Tension side

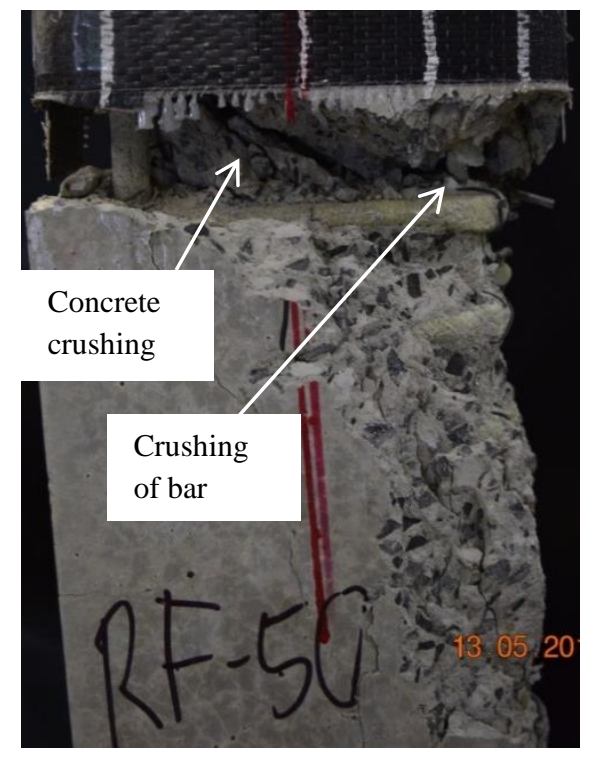

(b) Side- View

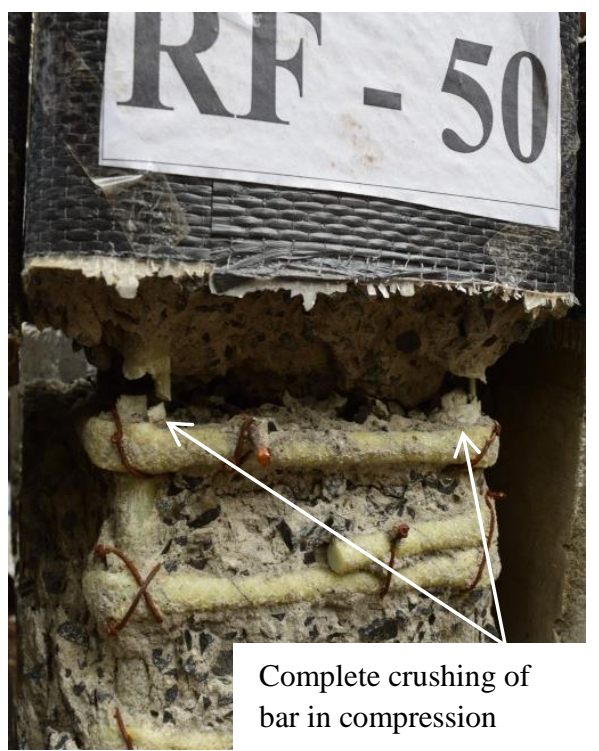

(c) Crushing of compression bars 
Fig 15.

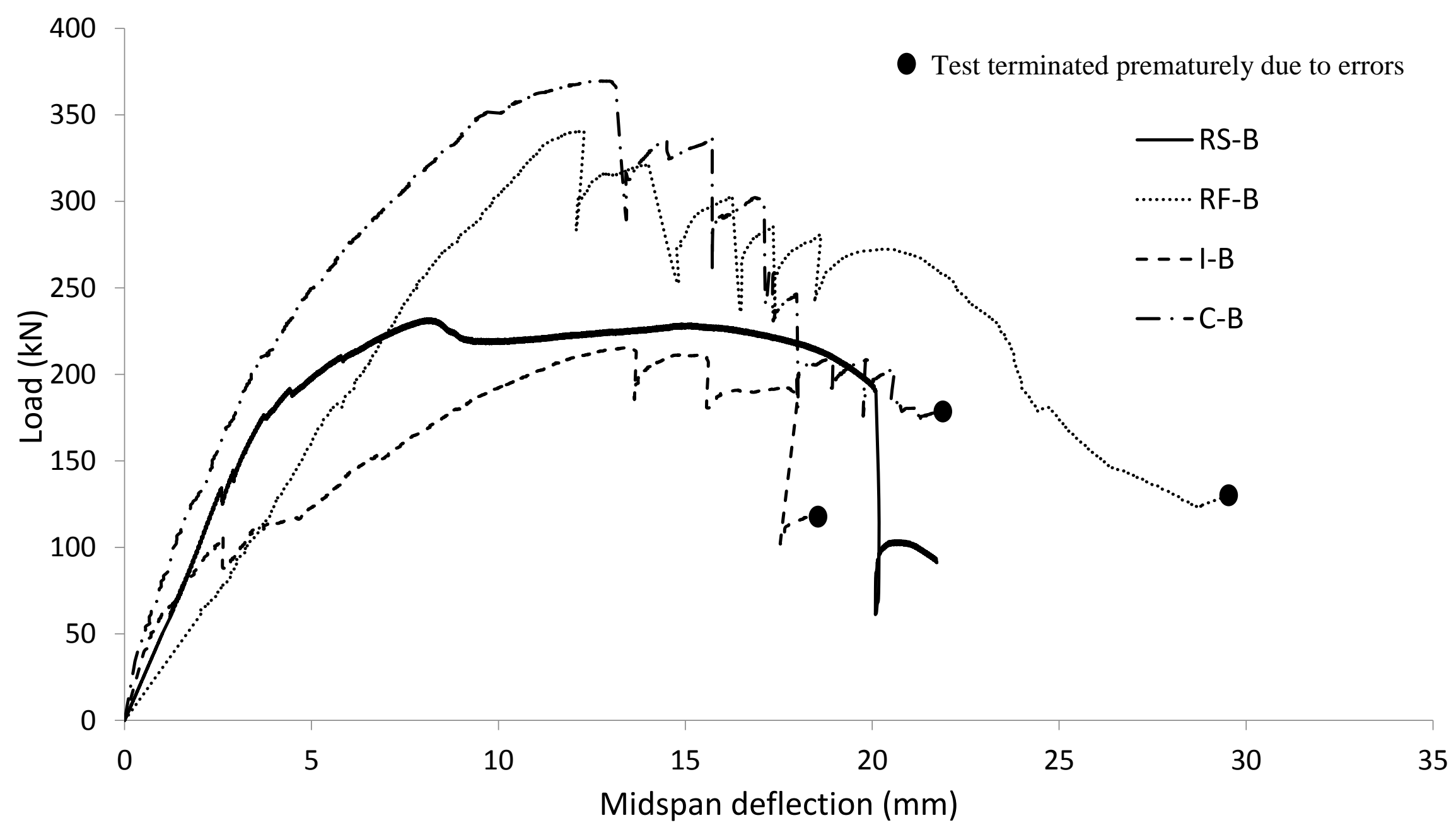


Fig 16.
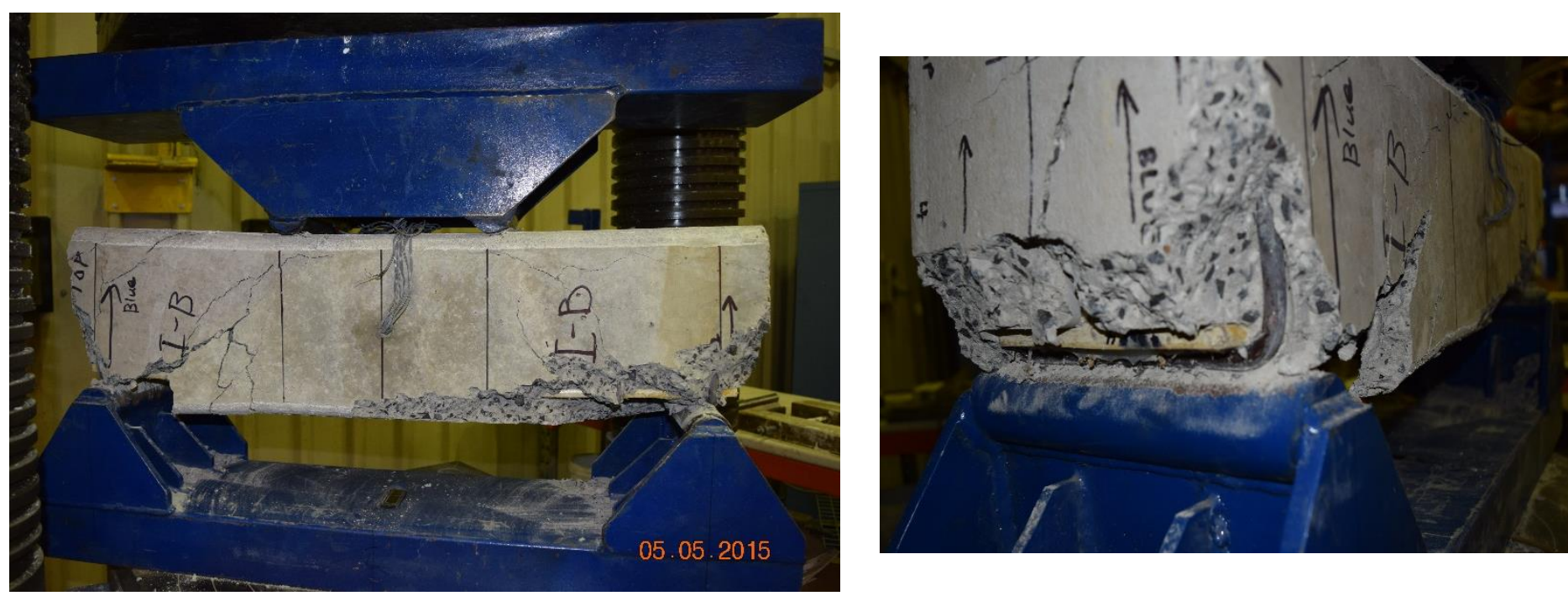
Fig. 17

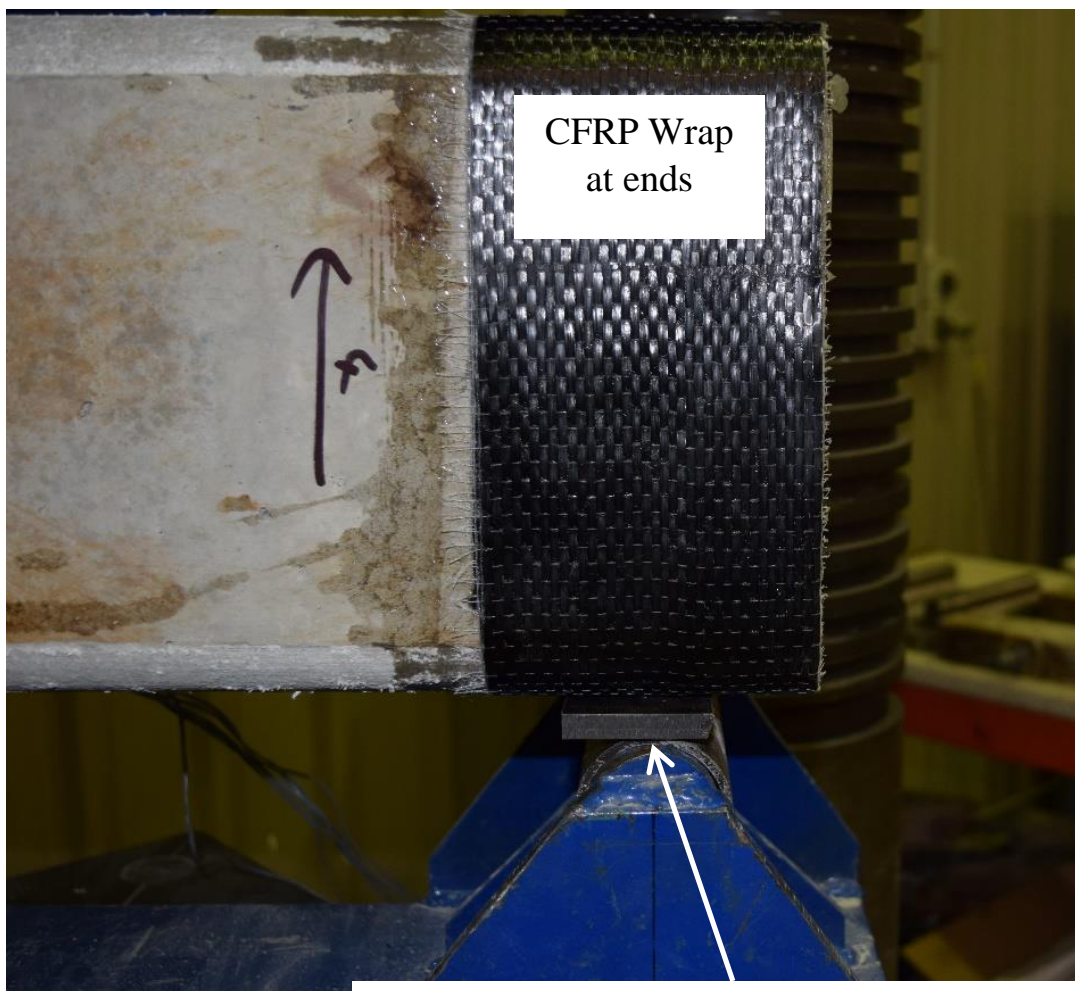

Steel bearing plate on the two supports 